\title{
GRK2 regulates GLP-1R-mediated early phase insulin secretion in vivo
}

\author{
Alba C. Arcones ${ }^{1}$, Rocío Vila-Bedmar ${ }^{2}$, Mercedes Mirasierra ${ }^{3}$, Marta Cruces-Sande ${ }^{1}$, Mario Vallejo ${ }^{3}$, Ben Jones ${ }^{4}$, \\ Alejandra Tomas ${ }^{5}$, Federico Mayor $\mathrm{Jr}^{1 *}$ and Cristina Murga ${ }^{1 *}$ (D)
}

\begin{abstract}
Background: Insulin secretion from the pancreatic $\beta$-cell is finely modulated by different signals to allow an adequate control of glucose homeostasis. Incretin hormones such as glucagon-like peptide-1 (GLP-1) act as key physiological potentiators of insulin release through binding to the $G$ protein-coupled receptor GLP-1R. Another key regulator of insulin signaling is the Ser/Thr kinase G protein-coupled receptor kinase 2 (GRK2). However, whether GRK2 affects insulin secretion or if GRK2 can control incretin actions in vivo remains to be analyzed.

Results: Using GRK2 hemizygous mice, isolated pancreatic islets, and model $\beta$-cell lines, we have uncovered a relevant physiological role for GRK2 as a regulator of incretin-mediated insulin secretion in vivo. Feeding, oral glucose gavage, or administration of GLP-1R agonists in animals with reduced GRK2 levels (GRK2+/- mice) resulted in enhanced early phase insulin release without affecting late phase secretion. In contrast, intraperitoneal glucoseinduced insulin release was not affected. This effect was recapitulated in isolated islets and correlated with the increased size or priming efficacy of the readily releasable pool (RRP) of insulin granules that was observed in GRK2+/- mice. Using nanoBRET in $\beta$-cell lines, we found that stimulation of GLP-1R promoted GRK2 association to this receptor and that GRK2 protein and kinase activity were required for subsequent $\beta$-arrestin recruitment.

Conclusions: Overall, our data suggest that GRK2 is an important negative modulator of GLP-1R-mediated insulin secretion and that GRK2-interfering strategies may favor $\beta$-cell insulin secretion specifically during the early phase, an effect that may carry interesting therapeutic applications.
\end{abstract}

Keywords: Insulin signaling, Incretin, G protein-coupled receptor kinase 2 (GRK2), Glucagon-like peptide 1 (GLP-1), $\beta$-arrestin, Granule dynamics

\section{Background}

Insulin is the major anabolic hormone controlling metabolic homeostasis. Consequently, the pancreatic $\beta$-cell is poised to rapidly adapt the rate of insulin secretion to fluctuations in blood glucose concentration by a complex array of regulatory mechanisms [1]. Upon increased

\footnotetext{
*Correspondence: fmayor@cbm.csic.es; cristina.murga@uam.es

'Departamento de Biología Molecular and Centro de Biología Molecular Severo Ochoa (CBMSO) UAM-CSIC; Instituto de Investigación Sanitaria Hospital Universitario La Princesa; CIBER de Enfermedades Cardiovasculares (CIBERCV), UNIVERSIDAD AUTONOMA DE MADRID and Instituto de Salud Carlos III, Madrid, Spain

Full list of author information is available at the end of the article
}

blood glucose levels, the canonical pathway of insulin secretion is activated following glucose entry in the $\beta$-cell through the GLUT2 transporter. Intracellular glucose undergoes glycolysis, increasing the ATP/ADP ratio and leading to closure of $\mathrm{K}^{+} / \mathrm{ATP}$-dependent channels. This results in membrane depolarization and activation of voltage-dependent $\mathrm{Ca}^{2+}$ channels, increasing intracellular calcium concentration and triggering pulsatile insulin secretion [1]. Besides, different extracellular mediators acting via $\mathrm{G}$ protein-coupled receptors (GPCRs) such as incretins, adrenergic, and muscarinic agonists, as well as signals from nutrient receptors, converge on the $\beta$-cell to finely modulate insulin release $[2-5]$.

(c) The Author(s). 2021 Open Access This article is licensed under a Creative Commons Attribution 4.0 International License, which permits use, sharing, adaptation, distribution and reproduction in any medium or format, as long as you give appropriate credit to the original author(s) and the source, provide a link to the Creative Commons licence, and indicate if changes were made. The images or other third party material in this article are included in the article's Creative Commons licence, unless indicated otherwise in a credit line to the material. If material is not included in the article's Creative Commons licence and your intended use is not permitted by statutory regulation or exceeds the permitted use, you will need to obtain permission directly from the copyright holder. To view a copy of this licence, visit http://creativecommons.org/licenses/by/4.0/ The Creative Commons Public Domain Dedication waiver (http://creativecommons.org/publicdomain/zero/1.0/) applies to the data made available in this article, unless otherwise stated in a credit line to the data. 
Insulin secretion occurs in a biphasic manner. The socalled early phase takes place during the first 10-15 min after feeding and represents the release of insulin already stored in granules. The more sustained late phase requires new synthesis and processing of insulin and can be modulated by the decrease in systemic glucose caused by the effects of insulin in tissues such as the muscle and the liver $[6,7]$. After insulin synthesis and granule maturation, most insulin granules (75-95\%) are stored within the $\beta$-cell cytoplasm, constituting the releasable pool (RP). A cortical actin network acts as a physical barrier between the RP and the readily releasable pool (RRP) of granules, which are primed at the cell membrane. This allows for rapid calcium-dependent fusion and insulin release from the RRP, which is especially relevant during the early phase [8-11].

The enteroendocrine system is an important modulator of early and late phase insulin secretion in the postprandial state. Specialized nutrient-sensing cells respond to food intake by releasing peptide hormones into the circulation, which act either directly on the $\beta$-cell, or indirectly via neural relays, and may account for $60-70 \%$ of total insulin release in healthy human subjects $[7,12]$. Of special relevance is the glucagon-like peptide 1 (GLP1 ), secreted by the L-cells of the small and large intestine following post-translational processing of the proglucagon gene. In $\beta$-cells, GLP-1 acts on the GLP-1 receptor (GLP-1R), a Gos-coupled class B GPCR that triggers a transient increase in CAMP, thus activating protein kinase $\mathrm{A}$ (PKA) and/or exchange protein directly activated by cAMP 2 (EPAC2) effectors. These signaling pathways potentiate glucose-induced closure of the $\mathrm{K}^{+} / \mathrm{ATP}$ channels and promote further $\beta$-cell depolarization and $\mathrm{Ca}^{2+}$ influx, ultimately leading to augmented insulin secretion [13-16]. The GLP-1R-EPAC2 pathway is also implicated in the potentiation of the early phase of insulin release by regulating insulin granule maturation, trafficking, and exocytosis [7, 17-19]. These processes are also modulated by GLP-1 stimulation of PKA, although its contribution to granule dynamics is less well established [20, 21]. The induction of insulin release only in the presence of high glucose (thus avoiding the risk of hypoglycaemia) and modulation of the early phase of insulin secretion account for the increasing use of GLP-1 mimetics in the treatment of type 2 diabetes (T2D) [16, 22-25].

$G$ protein-coupled receptor kinase 2 (GRK2), a product from the adrbk1 gene, is a Ser/Thr kinase classically known for its role in the regulation of GPCRs. GRK2 phosphorylates the active form of GPCRs, thus prompting the recruitment of $\beta$-arrestins and the uncoupling of $\mathrm{G}$ proteins. This leads to internalization of GPCRs and also triggers $\beta$-arrestin-dependent signals [26, 27]. Besides this canonical role, GRK2 is able to interact with other non-GPCR partners in a kinase-dependent or independent manner [28-31]. In particular, GRK2 acts as a negative regulator of insulin signaling by different mechanisms taking place downstream or at the level of the insulin receptor $[26,27,32]$. We have previously reported that GRK2 levels increase in several key metabolic tissues in experimental conditions promoting insulin resistance (IR) and that GRK $2+/-$ mice (the use of GRK2-/- animals is not experimentally possible since they die during embryogenesis [33]) are protected against high-fat diet (HFD)-induced obesity and IR. Also, reduction of GRK2 levels in mice with an already established obese phenotype is able to revert the obese and IR state $[27,34]$. These data point to the potential for beneficial effects of reducing GRK2 in key metabolic tissues such as the liver, muscle, and white adipose tissue. Interestingly, in rodent models and also in humans, the development of IR in different tissues promotes a compensatory effect in the pancreas that initially leads to hyperinsulinemia and ultimately triggers $\beta$-cell failure $[35,36]$.

In this report, we have addressed the potential role of GRK2 levels in pancreatic functionality in non-IR conditions using GRK2 hemizygous mice and $\beta$-cell models. Our results reveal that low levels of GRK2 enhance GLP-1R-mediated insulin secretion in vivo and in isolated islets. We also show that GLP-1R activation promotes GRK2 association and $\beta$-arrestin recruitment in a GRK2-dependent manner. In vivo, reduced GRK2 levels potentiate insulin release, particularly from the RRP of insulin granules, in response to the GLP-1R agonist Exendin-4. We also find that GRK2 modulates insulin secretion from the $\beta$-cell specifically during the early phase, which may have potential therapeutic implications.

\section{Results}

GRK2 protein expression in the pancreas is restricted to the pancreatic islets

The pancreas is a heterogeneous organ constituted by the exocrine pancreas (acinar and duct cells) and the endocrine pancreas (the islets) [37, 38]. In order to characterize the distribution of GRK2 protein expression in the pancreas, we performed immunohistochemical (IHC) detection in pancreatic sections of WT and GRK2 hemizygous (GRK2+/-) mice. GRK2 protein was restricted to the pancreatic islets, and no GRK2 staining was found in exocrine pancreatic tissue (Fig. 1a and Additional File 1: Supplementary Figure 1). GRK2+/mice display circa $50 \%$ of GRK2 protein levels compared with their WT littermates as quantified by Western blot both in lysates from whole pancreata (Fig. 1b) and from isolated islets (Fig. 1c). No apparent differences were revealed in islet mass by histological quantification of serial sections of the pancreas from WT and GRK2+/- 


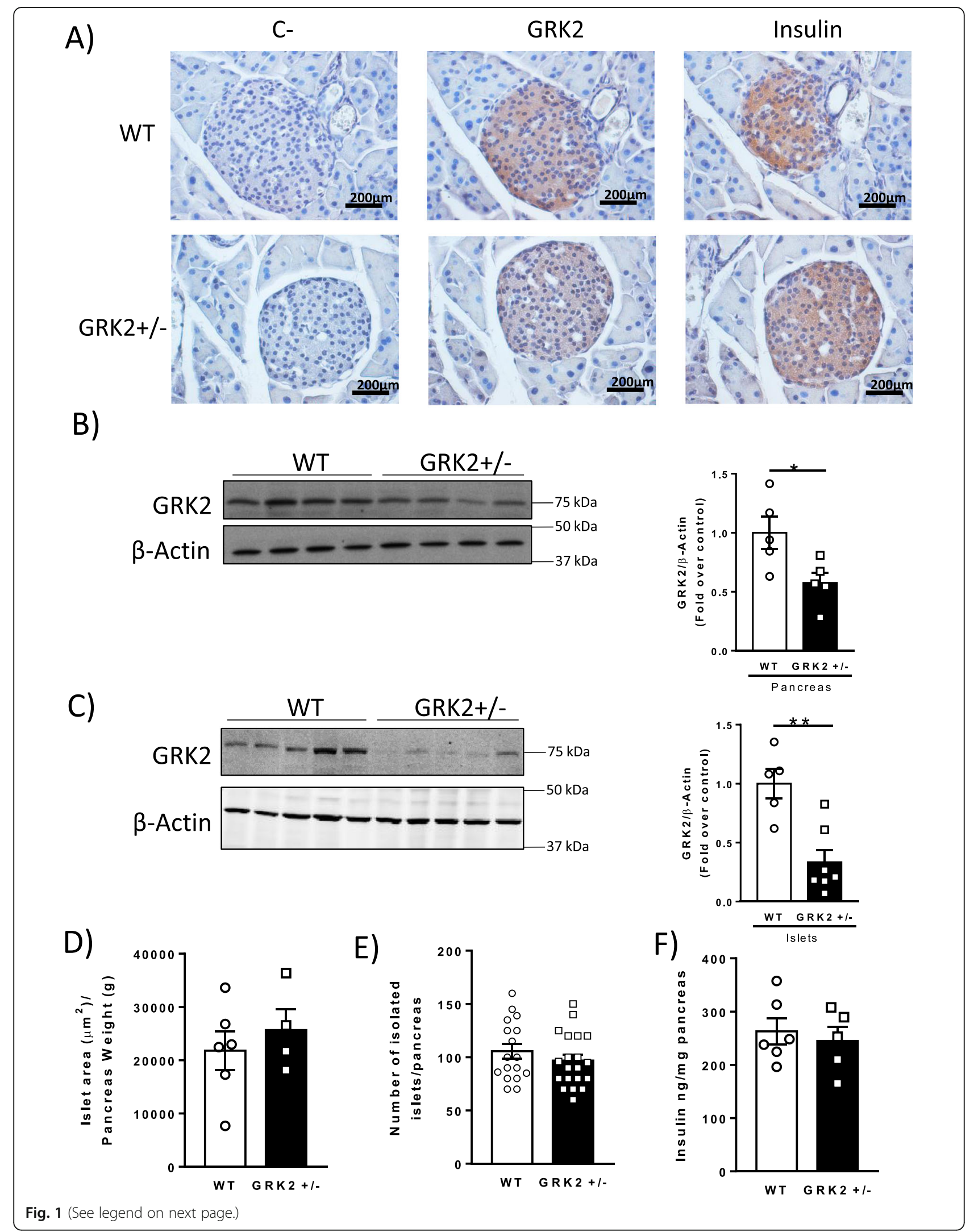


(See figure on previous page.)

Fig. 1 Specific localization of GRK2 in the pancreatic islet and expression levels of GRK2 protein in the pancreas of WT and GRK2+/- mice. Representative photomicrographs showing the immunohistochemical staining of serial pancreatic sections using antibodies against GRK2 or insulin as an islet marker, counterstained with hematoxylin (magnification $\times 40$; scale bar $0.2 \mathrm{~mm}$ ). Incubations without primary antibody are performed as a negative control (a). Whole pancreatic tissue lysates, WT $n=5$, GRK2 $+/-n=5$ (b) or isolated islets lysates, WT $n=5$, GRK2 $+/-n=$ 7 (c) were subjected to Western blot analysis and probed with antibodies against GRK2 and $\beta$-actin. Stereological analysis of the pancreas analyzing three pancreatic sections separated $0.4 \mathrm{~mm}$ (each whole section was imaged, with an average 30 islets detected per section: total 565 islets were counted in WT mice (average of 94 islets/mice in three sections) and 407 islets in GRK2+/- mice (average of 101 islets/mice in three sections), non statistically different by $t$ test), islet mass was quantified measuring insulin-positive area in WT $n=6$ and GRK2 $+/-n=4$ (d). Number of isolated islets per digested pancreas, WT $n=17, \mathrm{GRK} 2+/-n=20$ (e). Total pancreatic insulin content measured in acidic-extracts of pancreata by ELISA, WT $n=6$ GRK2 $+/-n=5$ (f). Means \pm SEM data are represented, statistical analysis was performed using unpaired $t$ test. ${ }^{*} p<0.05,{ }^{* *} p<0.01$

mice (Fig. 1d), in islet numbers obtained from these animals (Fig. 1e) or in total insulin levels as confirmed by acidic extraction from whole pancreata (Fig. 1f). These data reveal that GRK2 levels do not influence islet mass or pancreatic insulin content.

\section{GRK2+/- mice display increased insulin release during the early but not late phase of insulin secretion}

Given the specific localization of pancreatic GRK2 inside the islets, we set out to determine whether GRK2 expression could have an impact on islet function, first by investigating early and late phase insulin secretion in response to feeding in WT and GRK2+/- animals. GRK2+/- mice showed higher plasma insulin concentrations than WT littermates 10 min (early phase) but not $4 \mathrm{~h}$ (late phase) after ad libitum feeding (Fig. 2a). There were no differences in blood glucose levels between genotypes (Fig. 2b), making glucose availability an unlikely explanation for the observed disparity in insulin release.

The aforementioned data suggested that lower levels of GRK2 in the pancreas favor secretion of insulin after feeding. Apart from the insulinogenic effect caused by an increase in blood glucose, feeding also activates different signaling networks in the central nervous system, as well as incretin production by the gut and signaling by nutrient receptors [1]. Thus, we performed oral glucose tolerance tests (oGTTs) to promote both incretin secretion and increase blood glucose levels to synergistically trigger insulin secretion by the $\beta$-cell [39]. GRK2+/- mice displayed a markedly increased insulin secretion in oGTTs compared to WT littermates (Fig. 2c). This occurred only during the early (15 min) but not in the late $(30 \mathrm{~min})$ phase, even when the same concentration of gavage-elicited plasma glucose was observed (Fig. 2d), suggesting that the increased insulin secretion observed in GRK2+/- mice might be ascribed to incretin-mediated effects.

Biphasic insulin secretion from pancreatic $\beta$-cells is explained by the existence of two different pools of insulin secretory granules, the readily releasable pool (RRP) that is ready to be secreted during the early phase, and the releasable pool (RP), which needs to be first recruited to the plasma membrane in order to be released during the late phase [7]. To study in vivo granule distribution and its impact on insulin secretion dynamics, mice were subjected to arginine tolerance tests (ArgTTs). These tests serve to analyze the capacity of $\beta$-cells to release insulin from either the RRP or the RP pools after membrane depolarization [40, 41]. In particular, the first intraperitoneal arginine injection causes an initial depolarization wave that promotes insulin release from membraneproximal RRP granules. A subsequent second injection some minutes later serves to analyze insulin secretion from the RP pool since it promotes mobilization of RP granules to replenish the RRP. Interestingly, GRK2+/mice displayed increased insulin release only during the early RRP-secreting phase (Fig. 2e) but no differences were found in insulin released from RP-mobilized particles. Altogether, these data suggest that a differential distribution of stored insulin exists in GRK2+/- mice, with an increased size or priming/exocytotic efficiency of the RRP compared to WT animals, in the absence of significant differences in granule recruitment from the RP.

Overall, the increased early phase insulin secretion after ad libitum feeding and oGTT in GRK2+/- mice raises the possibility that $\beta$-cell responses to incretin hormones are modulated by GRK2 levels. Incretins are known to be implicated both in enhancing insulin secretion after an oral glucose bolus and in regulating the subcellular distribution of insulin granules mainly via EPAC2-dependent mechanisms [7, 18, 19].

Since GRK2 has been shown, in other cell types, to directly interact and inhibit the related EPAC1 isoform through phosphorylation [42], we set out to explore whether a decreased GRK2 dosage could directly influence EPAC2-dependent insulin secretion from pancreatic $\beta$-cells. We thus compared the effect of $\mathrm{K}^{+} / \mathrm{ATP}$ channel closing sulfonylureas (glicazide) and channel closing plus EPAC2-activating sulfonylureas (glibenclamide) in WT and GRK2+/- mice [43]. The results shown in Fig. $2 f$ indicate, in a limited number of animals, that insulin release is potentiated to the same extent in both genotypes by sulfonylureas regardless of whether they are also directly activating EPAC2 or not. 

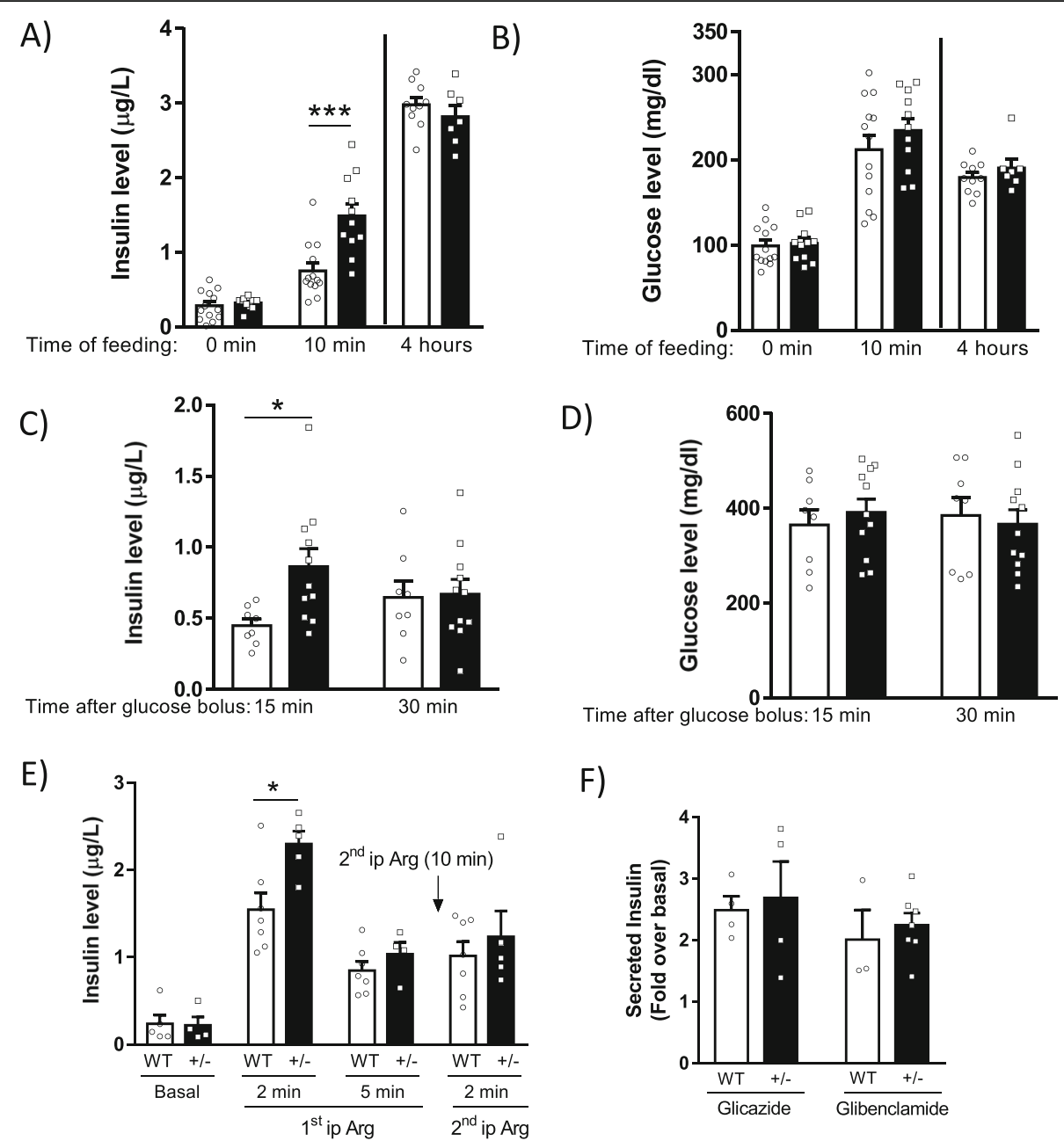

Fig. 2 Increased early phase insulin secretion and RRP size in GRK2+/- mice. Insulin (a) and glucose (b) were measured after feeding animals for $10 \mathrm{~min}$ (early phase insulin secretion) or $4 \mathrm{~h}$ (late phase) (same animals were used to assess insulin and glucose levels, WT $n=13,13,10$ and GRK2+/- $n=11,11,7$; for $0,10 \mathrm{~min}$, and $4 \mathrm{~h}$, respectively). oGTT (2 g/kg) was performed in WT and GRK2+/- mice, and insulin (c) and glucose levels (d) were assessed in serum samples $15 \mathrm{~min}$ (early phase) and $30 \mathrm{~min}$ (late phase) after a glucose gavage (same animals were used to assess insulin and glucose levels, WT $n=7$, GRK2 $+/-n=10$ ). To explore the status of different pools of insulin granules, mice were injected ip with $1 \mathrm{~g} /$ $\mathrm{kg}$ arginine (1st ipArg; measured at 2 and $5 \mathrm{~min}$ ) to elicit insulin secretion from the RRP. A second arginine injection 10 min later (2nd ipArg; measured 2 min later) reveals effects in replenishing the RRP from the RP. In both cases, insulin concentrations in serum are shown in the graph (WT $n=5,7,7,7$; GRK2 $+/-n=4,5,4,5$ for 0, 2, 5 min and 2 min after 2 nd ip Arg, respectively) (e). Mice were injected ip with the sulfonylureas glicazide $(10 \mathrm{mg} / \mathrm{kg}$ ) or glibenclamide $(5 \mathrm{mg} / \mathrm{kg}$ ). Insulin levels were measured at 0 and $15 \mathrm{~min}$ and fold increase in serum insulin levels is shown (glicazide: WT $n=4$, GRK2+/- $n=4$; glibenclamide: WT $n=3$, GRK2 $+/-n=7$ ) (f). Means \pm SEM data are represented, WT: White bars, GRK2+/-: Black bars, statistical analysis was performed by 1-way ANOVA followed by Bonferroni's post hoc test ${ }^{*} p<0.05 ;{ }^{* * *} p<0.01$

Altogether, these data argue in favor of the possibility that GRK2 does not modulate EPAC2 directly in pancreatic $\beta$-cells although additional research would be required to address this point.

GRK2 is recruited to the activated GLP-1R in pancreatic $\beta$ cell lines and is required for $\beta$-arrestin 2 association GRK2 may be influencing incretin-driven insulin release by a mechanism that lays upstream of EPAC2, possibly at the level of the incretin receptor. We thus assessed GRK2 recruitment to activated GLP-1R and its functional effects on $\beta$-arrestin and $G$ protein coupling using a nanoBRET-based assay in the rat pancreatic $\beta$ cell line INS-1 832/3. We observed a rapid and sustained translocation of GRK2 to the vicinity of GLP-1R after addition of Exendin-4, a well-established pharmacological agonist of this receptor [44] (Fig. 3a, b). Moreover, the recruitment of GRK2 to GLP-1R appears to be modulated by the biased signaling properties of GLP-1R ligands, as demonstrated by using previouslydescribed Exendin-4-based biased agonists [45]. As shown in Fig. 3c, d, the Gos-biased agonist Ex4-Phe1, known to display very reduced $\beta$-arrestin recruitment, promotes a lower association of GRK2 to GLP-1R. 


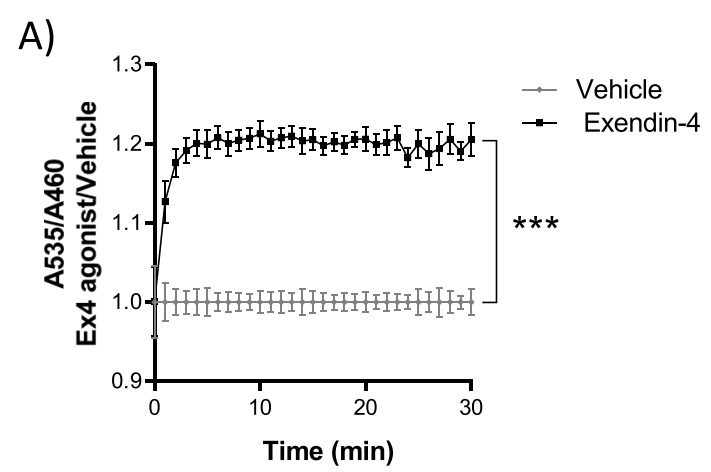

C)

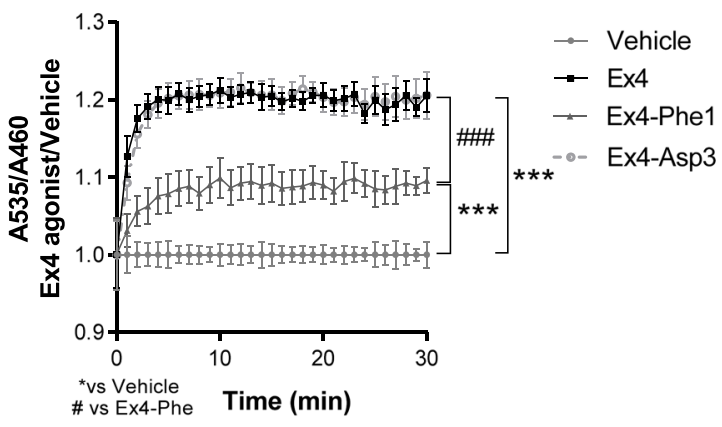

B)

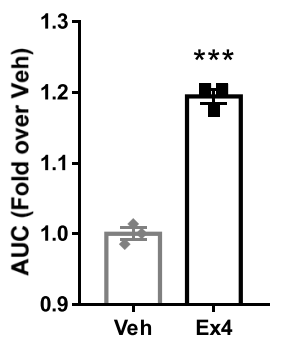

D)

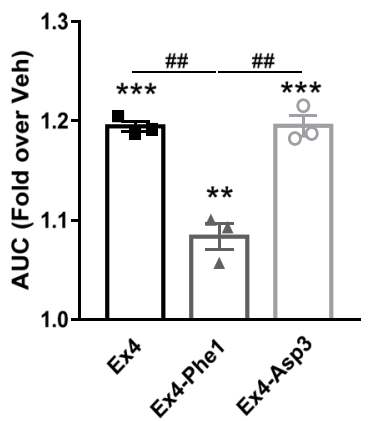

Fig. 3 GRK2 is recruited to the activated GLP-1R and this occurs to a different extent by biased agonists. GRK2 recruitment to GLP-1R was measured by nanoBRET in INS1 832/3 GLP-1R KO cells using 100 nM of Exendin-4 (a). AUC of GRK2 recruitment assay by nanoBRET (b), $n=3$ independent experiments, each point is an average from 3 to 4 technical replicas $(\mathbf{a}, \mathbf{b})$. The same experiment was performed in the presence of 100 nM of different Exendin-4 biased agonists: Ex4-Phe1 (Gas-biased) and Ex4-Asp3 ( $\beta$-arrestin biased) (c). AUC of GRK2 recruitment assay by nanoBRET (d). $N=3$ independent experiments, each point is an average from 3 to 4 technical replicas. Means \pm SEM data are represented, statistical analysis was performed using repeated measures two-way ANOVA (a, c) or paired one-way ANOVA (d) followed by Bonferroni's post hoc test and paired $t$ test $(\mathbf{b}),{ }^{* *}{ }^{\# \#} p<0.01,{ }^{* * *}{ }^{\# \# \#} p<0.001$

Conversely, the $\beta$-arrestin-biased peptide Ex4-Asp3 showed a similar recruitment of GRK2 as Exendin-4 itself. These results indicate that GRK2 is recruited to GLP-1R by Exendin-4 in $\beta$-cells and that agonists biased towards $\beta$-arrestin recruit GRK2 more efficiently than Gas-biased ones.

To further assess this, we quantified the association of Gos or $\beta$-arrestin 2 proteins to the activated GLP-1R using, in this latter case, the NanoBIT system (that leads to reconstitution of luciferase and light emission upon close interaction of fusion proteins) in Min6B1 $\beta$-cells with silenced or pharmacologically-inhibited GRK2. Using this system, we observed that a circa $50 \%$ reduction of GRK2 protein levels by transfecting siRNAs (Scrambled: siSc or $\alpha$ Adrbk1: siGRK2) (Fig. 4a) impairs $\beta$-arrestin 2 but does not change Gos recruitment to the agoniststimulated receptor (Fig. 4b). The same tendency was observed when GRK2 kinase activity is inhibited using the pharmacological inhibitor Compound 101 [46], which reduced the association of $\beta$-arrestin 2 but not of Gos to the activated GLP-1R (Fig. 4c). Overall, these results put forward that GRK2 can be recruited to the activated GLP-1R in $\beta$-cell lines, where it exerts modulatory actions in $\beta$ arrestin recruitment to this receptor.

\section{GRK2 modulates GLP-1R-mediated insulin secretion in vivo}

In order to determine whether changes in GRK2 levels could have an effect on GLP-1R-dependent enhancement of insulin secretion in vivo, we analyzed possible differences between WT and GRK2+/- mice in the potentiation of insulin release caused by Exendin-4. First, we found that the early phase insulin secretion stimulated by ip injection of glucose alone was indistinguishable in GRK2+/- animals compared to WT mice (Fig. 5a), contrary to the enhanced response observed upon feeding (Fig. 2a) or a glucose gavage (Fig. 2c), and coherent with the suggested involvement of incretins in the observed effect of GRK2 dosage.

Consistent with this notion, upon addition of Exendin4 to the ip glucose bolus, an enhancement in insulin secretion was detected in GRK2+/- mice compared to WT (Fig. 5a). Basal and early $(15 \mathrm{~min})$ blood glucose levels were also similar between genotypes in the 


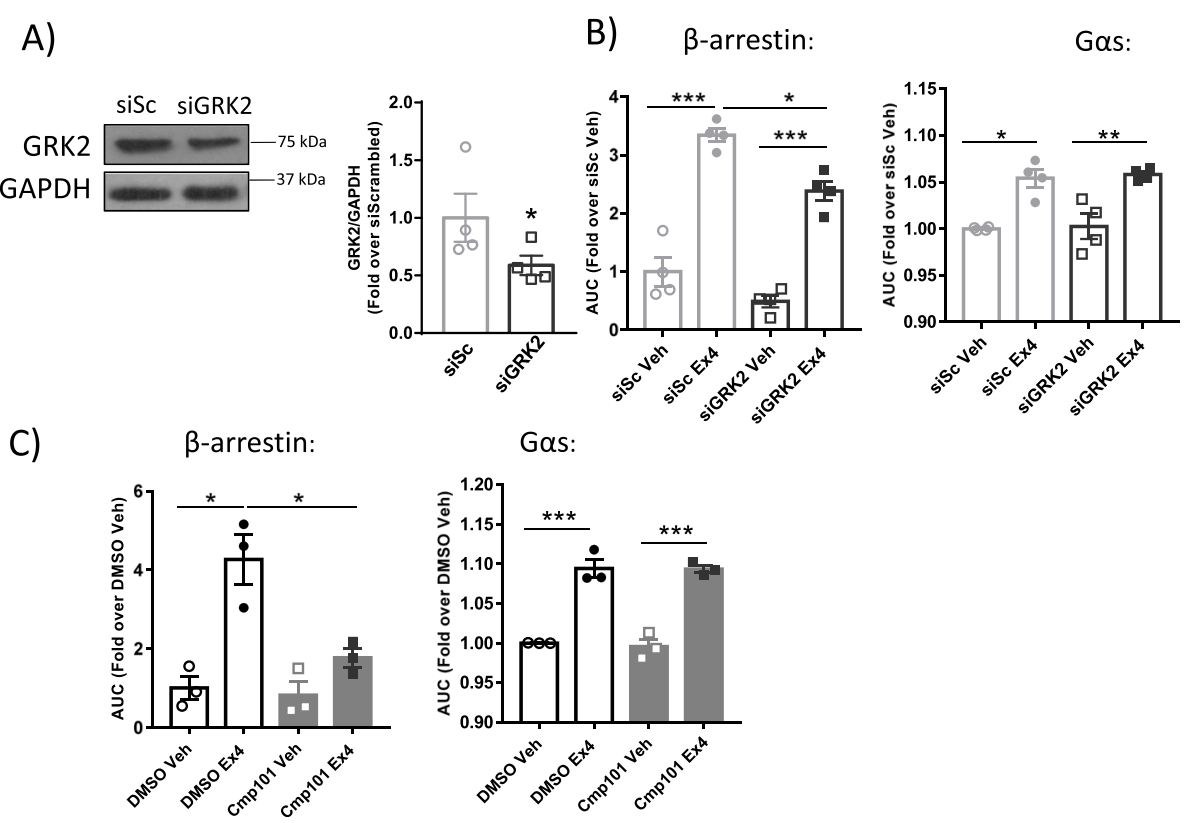

Fig. 4 GRK2 levels and activity can modulate $\beta$-arrestin 2 association. Western blot analysis of the level of GRK2 silencing in Min6B1 cells (siSc: siRNA Scrambled; siGRK2: siRNA aAdrbk1), $n=4$ independent experiments (a). AUC of $\beta$-arrestin 2 or Gas recruitment quantified by NanoBIT and nanoBRET, respectively, for 30 min after GLP-1R activation in Min6B1 cells silenced (b) or inhibited (c) for GRK2, $n=4$ (b) or 3 (c) independent experiments, each point is an average from 3 to 4 technical replicas. Means \pm SEM data are represented. Statistical analysis was performed by paired $t$ test (a) or paired one-way ANOVA followed by Bonferroni's post hoc test (b, $\mathbf{c}) .{ }^{*} p<0.05,{ }^{* *} p<0.01,{ }^{* * *} p<0.001$

different conditions tested (Fig. 5b), but the higher insulin secretion of GRK2+/- animals in response to Exendin-4 led to a decrease in blood glucose levels that was significantly different from that of WT mice at 30 min (Fig. 5c). A similar tendency towards decreased glucose levels during the Ex4-ipGTT in these mice was suggested by the AUC analysis (Fig. 5d).

To further confirm the implication of reduced GRK2 levels particularly in the pancreas in the observed phenotype, and to avoid the possible influence of reduced GRK2 in other tissues, Exendin-4-mediated stimulation of insulin secretion was measured in pancreatic islets isolated from WT or GRK2+/- mice. We observed an increased capacity to secrete insulin upon GLP-1R activation in islets isolated from GRK2+/- animals compared to WT mice (Fig. 5e). Moreover, this enhancement in GLP-1R-dependent insulin release occurred in the absence of differences in high glucosestimulated insulin secretion (Fig. 5e), or in total insulin (Fig. 5f) between genotypes.

In light of these results, we can conclude that GRK2 negatively regulates GLP-1R-mediated pancreatic insulin secretion and that decreasing GRK2 levels is able to boost incretin-dependent potentiation of insulin release in vivo.

\section{Discussion}

Overall, our data reveal a physiological role for GRK2 as a regulator of incretin-mediated insulin secretion in vivo, by modulating the GLP-1R pathway and RRP functionality (see scheme in Fig. 6). Early phase insulin release by feeding and oGTT (but not ipGTT) was enhanced in animals with reduced GRK2, as was Exendin4-induced insulin release in vivo and in isolated islet what supports that GRK2 regulates incretin-mediated responses.

Previous reports described that GRK2 may regulate GLP-1R using model systems. For instance, in HEK293 cells, GRK2 was demonstrated to interact with the GLP$1 \mathrm{R}$ by BRET $[47,48]$ and by FRET [49]. However, a functional implication of GRK2 in the regulation of GLP-1R in a physiologically relevant in vivo context had not been addressed to our knowledge. Our data show that in pancreatic $\beta$-cell lines, GRK2 interacts with the activated GLP-1R and that downregulation of GRK2 levels or pharmacological inhibition of its activity markedly impairs $\beta$-arrestin2 recruitment to the agoniststimulated receptor without apparent changes in Gos recruitment.

Of note, GRK2 is recruited to a different extent by the differently biased Exendin-4 agonists. Single amino acid $\mathrm{N}$-terminal modifications in Exendin-4 can bias GLP-1R agonism, and substituting histidine for phenylalanine in position 1, as in Ex4-Phe1, promotes a marked reduction in $\beta$-arrestin 1 and 2 recruitment. This leads to decreased GLP-1R degradation and increased chronic insulin secretion 
A)

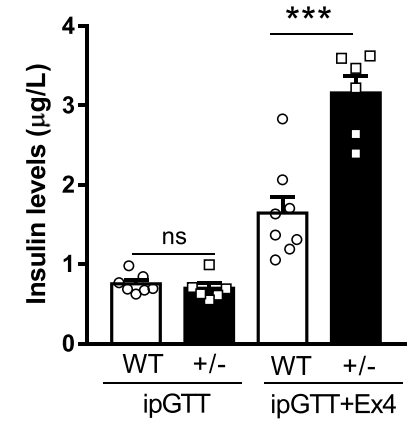

C)

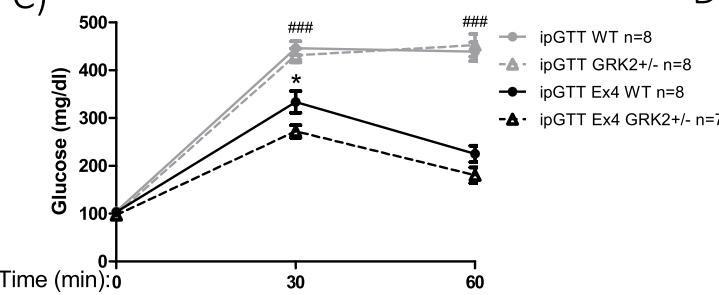

E)

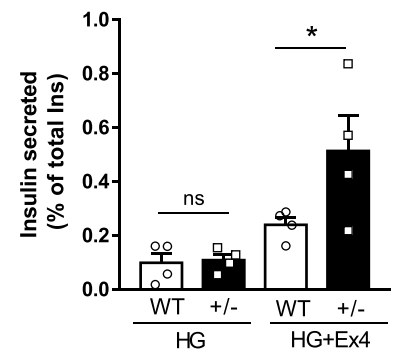

B)

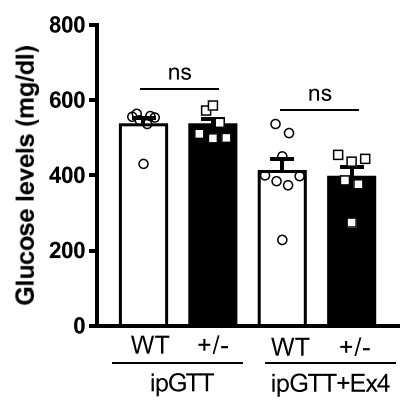

D)

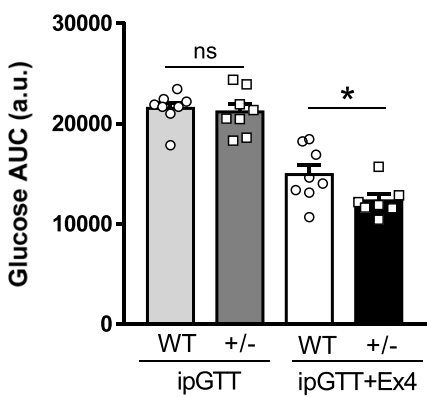

F)

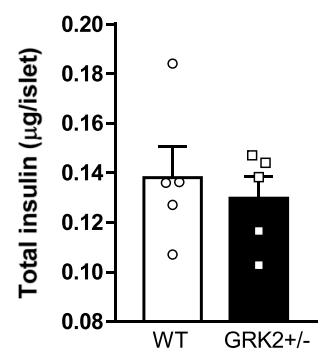

Fig. 5 GRK2 +/- mice display increased GLP-1R-dependent insulin release in vivo and in isolated islets. Insulin (a) and glucose (b) levels were assessed in serum samples of fasted mice (basal) and $15 \mathrm{~min}$ after the administration of an intraperitoneal glucose bolus (ipGT, $2 \mathrm{~g} / \mathrm{kg}$ ) with or without the GLP-1 analog Exendin-4 (Ex4, $5 \mu \mathrm{g} / \mathrm{kg}$ (for ipGTT or ipGTT+Ex4, respectively, WT $n=7$ or 8; for GRK2+/- $n=6$ or 6 ; same mice were used to assess insulin and glucose levels). Analysis of glucose levels (c) and bar graph representing the area under the curve (AUC) (d) after insulinogenic stimuli are shown; WT: $n=8$ for ipGTT and ipGTT + Ex4 and GRK2 $+/-n=8$ for ipGTT and 7 for ipGTT + Ex4. Insulin secretion in isolated pancreatic islets stimulated with high glucose (HG, $17 \mathrm{mM}$ ) or high glucose with Exendin-4 (HG + Ex4 $100 \mathrm{nM}$ ) from WT and GRK2+/mice, expressed as \% of insulin content, $n=4$ mice (2-3 different 5-islets pool were assessed per mice as technical replicas) (e). Amount of total islet insulin content as obtained by acidic extraction, $n=5$ mice (8-11 5-islets pools were assessed per mice as technical replicas) (f). Means \pm SEM data are represented. Statistical analysis was performed using repeated measures 2-way ANOVA (c) or 1-way ANOVA (a, b, d, and e) followed by Bonferroni's post hoc test and unpaired $t$ test $(\mathbf{f}) ;(*)$ was used for comparisons between WT and GRK2+/- mice, (\#) was used for comparisons between basal vs ipGTT or ipGTT vs ipGTT + Ex4 (C). ${ }^{*} p<0.05 ;{ }^{* * * \# \#} p<0.001$

that is also observed upon silencing of $\beta$-arrestin proteins [45]. Interestingly, our results show that Gos-biased GLP-1R agonists, such as Ex4-Phe1, promote a poorer recruitment of GRK2 as compared to Exendin-4 itself or to a $\beta$-arrestin-biased GLP-1R agonist (Ex4-Asp3). This speaks in favor of a mechanism by which the amount of GRK2 in the vicinity of GLP-1R could determine the efficacy of the subsequent association of $\beta$-arrestins to the phosphorylated receptor. The extent of recruitment of GRK2 would in turn depend on the agonist used (and the specific receptor conformation) as well as on the amount of GRK2 in the $\beta$-cell.
The absence of differences in Gos-GLP-1R recruitment with different levels or activity of GRK2 despite decreased $\beta$-arrestin recruitment in such conditions could be a surprising observation that might be explained by several facts. Plasma membrane-tethered G proteins have been shown to be basally preassembled with GPCRs in some cases [50,51], in contrast to cytoplasmic GRK2 or $\beta$-arrestins, that need to be recruited to the plasma membrane upon GPCR stimulation. Also, inactive $\mathrm{G}$ proteins may persist in the vicinity of GPCRs [52]. Furthermore, even when classical $\beta$-arrestin recruitment to GPCRs sterically blocks $G$ protein binding, a 


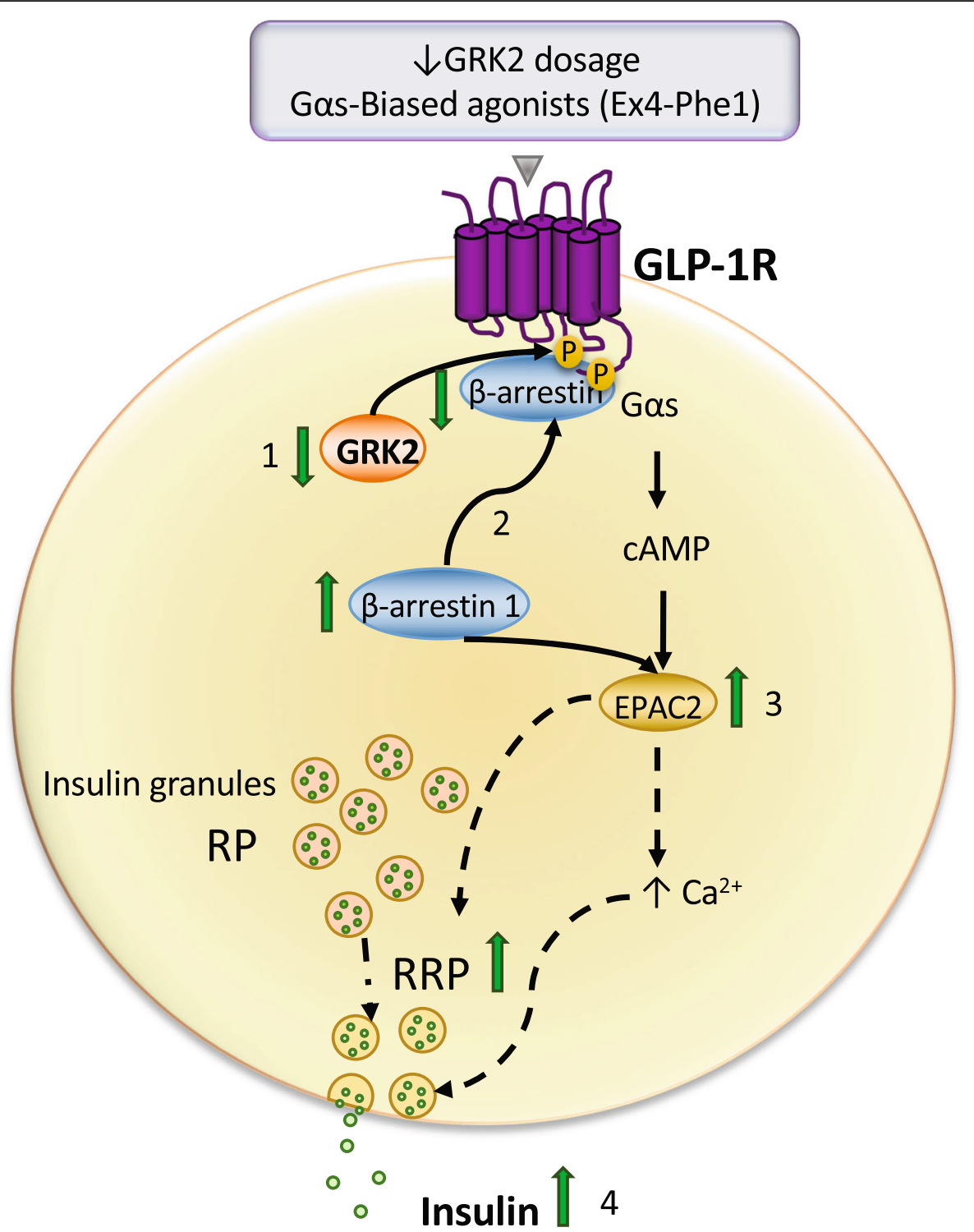

Fig. 6 Schematic representation of the proposed impact of GRK2 on GLP-1R actions in the $\beta$-cell. Upon GLP-1R activation in the $\beta$-cell GRK2 is recruited to the activated receptor (1). In a situation of reduced GRK2 dosage or upon stimulation with Gas-biased agonists (Ex-Phe1), less GRK2 would associate with GLP-1R leading to diminished $\beta$-arrestin recruitment (2) and reducing receptor desensitization. Also, these higher levels of free $\beta$-arrestin 1 could then activate EPAC2 (3), which would potentiate insulin secretion (4) in a dual manner: contributing to GLP-1R-mediated acute actions on insulin release $\left(\mathrm{Ca}^{2+}\right)$, as well as increasing the size or efficiency of the RRP. Dotted lines represent indirect mechanisms of action

ternary complex (termed "megaplex") formed by certain class B GPCRs, a G protein and $\beta$-arrestin has been described to mediate sustained signaling in endosomal compartments [53, 54], and endosomal Gas-signaling has been described from GLP-1R [55-57]. Pre-existing membrane complexes, permanence of inactive $G$ protein in the vicinity of GPCRs as well as co-association of Gos and $\beta$-arrestin to the GLP-1R would be consistent with the discrete fold-increase in exendin-mediated Gos recruitment observed compared to that of $\beta$-arrestin 2 and might contribute to explain the observed independence of Gos association from the recruitment of GRK2 and binding of $\beta$-arrestin, at least in model experimental systems involving overexpression of receptor and partner proteins.

In any case, our data suggest that GRK2 levels and activity are critical to efficiently recruit $\beta$-arrestins to the GLP-1R. One expected outcome of this effect is the GRK2-mediated modulation of $\beta$-arrestinmediated desensitization and thus of the canonical GLP-1R-dependent signaling pathways known to modulate insulin release. While we did not measure downstream signaling responses in $\beta$-cells after GRK2 knockdown, previous literature describes increased 
Gos-mediated signaling upon GRK2 depletion or inhibition [58-61]. Moreover, GRK2 has been already shown to negatively regulate GLP-1R-stimulated cAMP production in COS7 cells [62] and also GIPRmediated cAMP increase in a $\beta$-cell line negatively impacting insulin secretion [63].

However, it is worth mentioning here that GRK2 dosage may also modify the $\beta$-arrestin-dependent signaling cascades alternatively or in addition to the cAMP branch. The role of $\beta$-arrestins on insulin secretion remains controversial, with varying conclusions depending on the specific experimental conditions. On the one hand, $\beta$-arrestin- 2 knock-out (KO) or tamoxifen-induced depletion have been shown to negatively affect glucosemediated insulin secretion, with no apparent effect on GLP-1R-dependent responses on perfused islets $[64,65]$. Conversely, islets from $\beta$-arrestin $2 \mathrm{KO}$ mice show decreased levels of membrane-docked granules, what affects GLP-1R-mediated insulin secretion [66]. In turn, $\beta$ arrestin $1 \mathrm{KO}$ broadly attenuates GLP-1 signaling in INS1 cells [67], while tamoxifen-induced depletion of $\beta$ arrestin 1 in mice induced no effect in Exendin-4 responses [43]. Interestingly, however, $\beta$-arrestin1 promotes insulin secretion via direct interaction with EPAC2, thus favoring EPAC2-induced Rap1 activation and potentiating sulfonylurea-induced insulin release [43]. It is thus tempting to suggest that in addition to modulating GLP-1R desensitization and thus the GLP$1 \mathrm{R} / \mathrm{Gs} / \mathrm{cAMP}$ axis, GRK2 may regulate GLP-1Rdependent insulin release by sequestering $\beta$-arrestin1 away from EPAC2 (see scheme in Fig. 6). Thus, in addition to a potential effect in fostering GLP-1Rstimulated cAMP production, decreased GRK2 levels could reduce incretin-induced GLP-1R phosphorylation and subsequent recruitment of $\beta$-arrestins, thus leaving more $\beta$-arrestin 1 available to exert its positive effects on EPAC2. Increased levels of GRK2 would promote the opposite effects. This model would also be consistent with the reported potentiation of insulin release by GLP$1 \mathrm{R}$ biased-agonists that trigger a reduction in $\beta$-arrestin recruitment $[45,68-70]$. Compared to other experimental systems, in our in vivo conditions, neither GRK2 nor $\beta$-arrestins are completely depleted, likely reflecting a more physiological situation. Thus, we can more soundly ascribe the final enhancement of Exendin-4-mediated insulin secretion to GRK2-dependent deficiency impinging on $\beta$-arrestin recruitment in the absence of additional confounding effects.

Our data point to an implication of GRK2 in finely regulating the functionality of insulin granules. Insulin release from the $\beta$-cell occurs initially from the granules of the RRP, and subsequently by the mobilization of granules from the RP which refill the RRP $[10,71]$. Interestingly, the size of the RRP directly correlates with the amount of insulin being released during the early phase [7, 71, 72]. By using arginine tolerance tests, we detect an increased size/efficiency of the RRP in GRK2 hemizygous mice in the absence of significant differences in the recruitment of vesicles from the RP. So, the increased amount of RRP insulin granules in GRK2+/mice might explain the differences observed between genotypes in the early phase of insulin release, mostly dependent on the RRP, and also the absence of differences in the late phase, mostly dependent on the RP.

The detailed molecular mechanisms linking GRK2 to $\beta$-cell granule dynamics remain to be determined. Nonetheless, since the GLP-1R/EPAC2 pathway is a known regulator of granule dynamics [7], it is plausible to speculate that direct or indirect GRK2-dependent regulation of the GLP-1R/ $\beta$-arrestin $1 /$ EPAC2 axis is playing a role (see scheme in Fig. 6). GLP-1R-mediated potentiation of insulin secretion is required to surpass the constitutive "braking state" of the $\beta$-cell, leading to an increase in $\mathrm{Ca}^{2+}$ levels that is sufficient to elicit emptying of the RRP $[7,73]$. This might explain the absence of differences on insulin secretion between WT and GRK2+/ - mice when glucose is used as the only secretagogue, an effect that is also observed in isolated islets. Thus, a regularly enhanced response of the GLP-1R pathway, as expected to occur in GRK2+/- mice after each feeding cycle compared to WT animals, would favor more robust repetitive cycles of granule priming and transport what could be the ultimate cause for the enlarged size/ functionality of the RRP observed in these animals.

Interestingly, loss of early phase insulin secretion, which our data propose to be affected by GRK2 dosage, is an early predictor of T2D onset at a time when only fasting glucose impairment has been established [7476]. Among current treatments for T2D, GLP-1R agonists stand out as one of the most promising [55, 7779]. Activation of the GLP-1R pathway is able to recover both the first and second phase of insulin secretion in human T2D patients [80]. Furthermore, GLP-1R agonists have a protective action on the $\beta$-cell, as well as on other tissues such as the liver and the brain [81, 82]. However, resistance to GLP-1 has been reported in diabetic patients $[83,84]$, which may challenge the effectiveness of treatments with GLP-1 mimetics.

Of note, previous reports have demonstrated that the level of GRK2 in different tissues is increased in situations of obesity and IR [34, 85-87]. This increase has been related with decreased insulin sensitivity and upregulation of pathology-related signaling pathways [85, 86]. Interestingly, a recent proteomics study indicated dynamic changes in islets protein levels of GRK2 in the $\mathrm{db} / \mathrm{db}$ T2D mice model, with GRK2 being upregulated in hyperglycemic vs euglycemic conditions and GLP-1R displaying an opposite modulation pattern [88, 89]. 
Although the modulation of GRK2 levels inside the $\beta$ cell upon non-genetic IR conditions is still to be characterized, it is tempting to postulate that a potential upregulation of GRK2 could impinge on both early and late events modulated by the GLP-1R during disease progression.

\section{Conclusions}

Taken together, our results indicate that interfering with GRK2 levels can modify GLP-1R-mediated insulin secretion in vivo specifically in the early phase which has particular interest for finding alternative or combined treatments for T2D in human patients.

\section{Methods}

\section{Animal protocols}

Experiments were performed using young ( 3 months old) male C57BL/6 J (WT) mice and mice made hemizygous for GRK2 (GRK2+/-, [33]) maintained on the C57BL/6 J background. Animals were bred at a room temperature of $22 \pm 2{ }^{\circ} \mathrm{C}$ on a 12:12 light-dark cycle (lights on at 08:00 am) with a relative humidity of $50 \pm$ $10 \%$ and under pathogen-free conditions in the animal facility of the Centro de Biologia Molecular Severo Ochoa with free access to food and water. Mice were euthanized using $\mathrm{CO}_{2}$ or cervical dislocation, and body and pancreas weight was measured. Before group assignation, animals were weighted and distributed in the different experimental groups randomly to avoid differences in body weight. All animal experimentation procedures conformed to the European Guidelines for the Care and Use of Laboratory Animals (Directive 86/ 609) and were approved by the Ethical Committees for Animal Experimentation of the Universidad Autonoma de Madrid (PROEX 48/15).

\section{Insulin secretion and glucose measurements}

Insulin was determined in serum from blood drawn after feeding or intraperitoneal (ip) injections of Exendin-4 or sulfonylurea, and also during oral (o) and ip glucose tolerance tests (oGTT and ipGTT, respectively), or Larginine tolerance tests (ArgGTT). Blood was extracted from the mandibular vein at the indicated time points and glucose was quantified immediately using an automatic analyzer (One Touch Ultra, LifeScan). In Fig. 5c, $\mathrm{d}$, glucose was quantified using blood from the tail vein.

For the analysis of insulin levels, blood was allowed to clot after collection by leaving it undisturbed at room temperature for $30 \mathrm{~min}$. The clot was removed by centrifugation at $1000 \mathrm{~g}$ for $15 \mathrm{~min}$ in a refrigerated centrifuge, the resulting supernatant constituting the serum. Insulin content was measured in $10 \mu \mathrm{l}$ of serum using an ELISA assay (Mouse Ultrasensitive Insulin ELISA, Mercodia).
To quantify insulin secretion after feeding, mice were fasted for $24 \mathrm{~h}$ and then allowed to eat standard diet pellet (Diet 150, Safe Diets) during the indicated time periods. For oGTT and ipGTTs, mice were fasted overnight for $14 \mathrm{~h}$ and $2 \mathrm{~g} / \mathrm{kg}$ glucose (Merck, $0.2 \mathrm{~g} / \mathrm{ml}$ dissolved in $0.9 \% \mathrm{NaCl}$ ) was administered by gavage or ip injection, respectively. To assess responses to GLP-1R agonists, Exendin-4 (MedChem Express, $5 \mu \mathrm{g} / \mathrm{kg}$ body weight dissolved in $0.2 \mathrm{~g} / \mathrm{ml}$ glucose saline solution) was administered ip [20].

To study the dynamics of insulin release, L-arginine (Merck, $1 \mathrm{~g} / \mathrm{kg}$ body weight dissolved in $0.9 \% \mathrm{NaCl}$ ) was injected ip in animals fasted for $14 \mathrm{~h}$ to depolarize the $\beta$ cell $[40,90]$ and thus elicit the secretion of insulin from the readily releasable pool (RRP) of insulin granules. A second ip administration of L-arginine $(1 \mathrm{~g} / \mathrm{kg}$ body weight) was performed $10 \mathrm{~min}$ after $1 \mathrm{st}$ ip injection to assess the replenishment of the RRP from the RP (Releasable Pool) [40].

To explore EPAC2-mediated insulin secretion mice were fasted for $1 \mathrm{~h}$ and injected ip with EPAC2activating (glibenclamide, $5 \mathrm{mg} / \mathrm{kg}$ ) or non-activating (glicazide, $10 \mathrm{mg} / \mathrm{kg}$ ) sulfonylureas (MedChem Express) in 5\% DMSO in sunflower oil [43].

\section{Isolation, islet number and insulin secretion from primary murine islets}

Pancreatic islets were isolated from WT or GRK2 +/male mice by perfusion through the bile duct, as previously described [91]. Briefly, the pancreas was inflated with $5 \mathrm{ml}$ of Hank's balanced salt solution (HBSS, $\mathrm{Ca}^{2+}$, $\mathrm{Mg}^{2+}$ free, Gibco) with $0.6 \mathrm{mg} / \mathrm{ml}$ collagenase NB8 (Serva). Then, tissue was dissected and digested for $1 \mathrm{~h}$ at $37^{\circ} \mathrm{C}$ with continuous agitation. Pancreatic islets were hand-picked and separated from the surrounding acinar tissue.

For quantification of islets number of digested WT and GRK2+/- pancreata, isolated islets were counted manually by microscopic observation after separation of the surrounding acinar tissue. Those animals, in which an incomplete perfusion of the pancreas was observed, were excluded from the final analysis (excluded mice numbers were WT $n=4 / 21$ GRK $2+/-n=4 / 24)$.

For insulin secretion assays, isolated primary islets were cultured overnight using a 5.4-mM glucose RPMI 1640 medium. Sixteen hours after isolation, islets were transferred to Krebs-Ringer Bicarbonate Hepes (KRBH) buffer: $2 \mathrm{mM} \mathrm{NaHCO}_{3}, 140 \mathrm{mM} \mathrm{NaCl}, 3.6 \mathrm{mM} \mathrm{KCl}, 0.5$ $\mathrm{mM} \mathrm{NaH} \mathrm{PO}_{4}, 0.5 \mathrm{mM} \mathrm{MgSO} 4,1.5 \mathrm{mM} \mathrm{CaCl}_{2}$, and 10 $\mathrm{mM}$ Hepes, supplemented with $1 \% \mathrm{BSA}$ and $3 \mathrm{mM}$ glucose for $1 \mathrm{~h}$. Subsequently, five size-matching islets were selected per technical replica and transferred to $17 \mathrm{mM}$ glucose (high glucose) or $17 \mathrm{mM}$ glucose + $100 \mathrm{nM}$ Exendin-4 (high glucose + Ex4) KRBH to measure 
insulin secretion. One hour later, islets were centrifuged for $3 \mathrm{~min}$ at $400 \mathrm{~g}$, supernatant was conserved for secreted insulin determination and total insulin was extracted using acidified ethanol $(0.135 \mathrm{M} \mathrm{HCl}$ in $75 \%$ ethanol). Insulin levels were analyzed using Mouse Insulin ELISA (Mercodia) and secreted insulin was expressed as \% of total insulin content in the pancreatic islets.

\section{Immunohistochemistry (IHC)}

Detection of insulin (anti-Insulin Novus NBP1-19803 antibody, RRID: AB_1642425, dilution 1:200) and GRK2 (anti-GRK2 "PF2" antibody [92], dilution 1:500) was performed in mouse pancreatic tissue sections deparaffinized and rehydrated prior to antigen retrieval using citrate buffer (10 mM Sodium Citrate, 0.05\% Tween 20, $\mathrm{pH}$ 6.0), microwave-heated to boiling temperature twice. Endogenous peroxidase activity was quenched by incubation in $3 \% \mathrm{H}_{2} \mathrm{O}_{2}$ for 10 min before slides were washed and blocked in 5\% Donkey Serum in PBS (blocking solution). Antibodies were incubated overnight at $4{ }^{\circ} \mathrm{C}$ in blocking solution including a negative control without primary antibody. Secondary antibodies (1:2000; BiotinSP-conjugated Donkey Anti Rabbit, Jackson ImmunoResearch) were incubated in PBS for $1 \mathrm{~h}$ at room temperature and signal was amplified using the ABC Kit (Vector Laboratories) for $30 \mathrm{~min}$. After washing, tissue sections were developed with 3,3'-diaminobenzidine (DAB) under the microscope. Finally, they were counterstained with hematoxylin and mounted with DPX (Sigma). Images were taken with a Zeiss Axioimager microscope. Pancreatic sections from tamoxifeninducible GRK2-/- mice (Tx-GRK2-/-) animals [34] were used to assess the specificity of the GRK2 antibody (see Additional file 1: Supplementary Figure 1).

\section{Quantification of $\beta$-cell mass and total insulin content}

Islet $\beta$-cell mass was measured as insulin-positive areas in IHC sections separated by $400 \mu \mathrm{m}$ to obtain a stereological analysis of the pancreas. Whole pancreatic sections were photographed at $\times 4$ magnification (Zeiss Axioimager microscope), and all sections of the pancreas were counted, detecting an average of 30 pancreatic islets per section. Quantification of islet mass area was performed using the FIJI Software. Total insulin content of the pancreas was analyzed by acidic extraction of insulin protein as described [20]. Briefly, pancreata were dissected, sonicated in acidified ethanol $(0.135 \mathrm{M} \mathrm{HCl}$ in $75 \% \mathrm{EtOH}$ ) and centrifuged at maximal speed for $1 \mathrm{~h}$. Insulin was measured from the supernatant using Mouse Insulin ELISA (Mercodia).

\section{Western blot}

For whole-pancreas lysates, complete pancreatic tissue was homogenized in $1.5 \mathrm{ml}$ of hypotonic lysis buffer as previously described for cardiac tissue [93] using metal beads in a Tissue Lyser (Qiagen) with two 2-min pulses of $1 / 30$ s speed. Pancreatic islets and cultured cells were ruptured in lysis buffer by bath sonication and centrifuged before protein concentration was measured in the supernatant by ABC (Bio-Rad) or Lowry standard methods.

$40-50 \mu \mathrm{g}$ (whole pancreas) or $10-30 \mu \mathrm{g}$ (cell or islets) of total protein lysates per lane were resolved by SDSPAGE and transferred to nitrocellulose or PVDF membranes. Blots were probed with specific antibodies against GRK2 (sc-562, Santa Cruz Biotechnology, Batch number: J0615, 1:1000), ß-Actin (Sigma Sigma A5441, RRID: AB_476744, Batch number: 0000088070, 1:2000), GAPDH (14C10, Cell Signaling, RRID: AB_10693448, 1: 1000) and developed using enhanced chemiluminescence (ECL; Amersham Biosciences) or the Odyssey Infrared Imaging System (Li-Cor Biosciences). Films were scanned with a GS-700 Imaging Densitometer and analyzed with Quantity One Software (Bio-Rad), or using an Odyssey Classic reader and the Odyssey software package 3.0 (Li-Cor Biosciences).

\section{GRK2, Gas, and $\beta$-arrestin recruitment assays in $\beta$-cell lines}

Recruitment of GRK2 to GLP-1R was measured in INS1 832/3 GLP-1R knock-out (KO; a gift from Dr Jacqueline Naylor, MedImmune, Astra Zeneca), a rat insulinoma cell line deficient for GLP-1R that was generated by CRISPR-Cas9 deletion of the GLP-1R in a INS1 832/3 background as previously described [94]. Cells were maintained in RPMI supplemented with 10\% FBS, $1 \mathrm{mM}$ sodium pyruvate, $10 \mathrm{mM}$ Hepes, $1 \%$ penicillin/streptomycin, and $0.4 \% \beta$-Mercaptoethanol. For GRK2 recruitment assays, cells were transfected with Lipofectamine 2000 with $0.5 \mu \mathrm{g}$ GRK2-Venus (kindly provided by Dr. Meritxell Canals [95]) and $0.5 \mu \mathrm{g}$ of a GLP-1R-NanoLuc plasmid, generated in house by PCR cloning of the nanoLuciferase sequence from pcDNA3.1-ccdB-Nanoluc (a gift from Mikko Taipale; Addgene plasmid \# 87067) onto the C-terminus end of the SNAP-GLP-1R vector (CisBio), followed by site-directed mutagenesis of the GLP-1R stop codon. Cells were detached $24 \mathrm{~h}$ later and resuspended in a solution of the luminescent substrate NanoGlo ${ }^{\circledR}$ Live Cell Assay System (Promega, diluted 1:20 in HBSS). GRK2 recruitment to active GLP-1Rs was measured after the addition of $100 \mathrm{nM}$ Exendin- 4 by quantifying nanobioluminescence resonance energy transfer (nanoBRET) between nanoluciferase (460 nm emission) and Venus (excited at $460 \mathrm{~nm}$ and emitting at $535 \mathrm{~nm}$ ) proteins [96, 97]. Recruitment was quantified during $30 \mathrm{~min}$ as $535 \mathrm{~nm}$ over $460 \mathrm{~nm}$ fluorescence ratio in live cells at $37^{\circ} \mathrm{C}$ using FlexStation3 and the SoftMaxPro 5 software (Molecular Devices). 
Min6B1 (a kind gift from Prof. Philippe Halban, University of Geneva), a clonal subline derived from the mouse insulinoma cell line Min6 [98, 99], was maintained in DMEM supplemented with 15\% FBS, 1\% penicillin/streptomycin, and $0.4 \% \quad \beta$-Mercaptoethanol. For Gas recruitment [100], cells were transfected with $0.5 \mu \mathrm{g}$ miniGs-Venus (a gift from Dr Nevin Lambert, Medical College of Georgia [52]) and $0.5 \mu \mathrm{g}$ GLP-1R-nanoLuc plasmids, and recruitment was quantified by nanoBRET $24 \mathrm{~h}$ after transfection as above.

$\beta$-arrestin 2 recruitment was studied in Min6B1 cells using $\mathrm{NanoBIT}^{\circ}$ (Promega) technology in which the two subunits of the nanoluciferase (Large (Lg)-BiT and Small (Sm)-BiT) are expressed as fusions with potentially interacting partners. Close proximity between the two subunits reconstitutes luciferase activity producing a luminescent signal, indicating partner interaction [101]. Min6B1 cells were transfected with $0.05 \mu \mathrm{g}$ of $\beta$-arrestin2-Lg-BiT (plasmid no. CS1603B118, Promega) and $0.05 \mu \mathrm{g}$ of GLP-1R-Sm-BiT (generated by in-frame cloning of the SmBiT tag at the C-terminus of the GLP-1R by substitution of the Tango sequence on a FLAGtagged GLP-1R-Tango expression vector (a gift from Dr. Bryan Roth, University of North Carolina, Addgene plasmid \# 66295 [102]). Cells were resuspended in NanoGlo ${ }^{\circ}$ Live Cell Assay System solution 24 h post-transfection to quantify luminescence. $100 \mathrm{nM}$ Exendin-4 was used to activate GLP-1R and induce $\beta$-arrestin 2 recruitment. For modulation of GRK2 levels or activity, Min6B1 were transfected with Lipofectamine 2000 with 25 pmol of Scrambled (siSc; D-001810-01-05, Horizon) or aAdrbk1 siRNA (siGRK2; L-040967-00-0005, Horizon) for $48 \mathrm{~h}$, or treated with the GRK2/3 inhibitor Compound 101 (30 $\mu \mathrm{M}$, Takeda [46]) $30 \mathrm{~min}$ before and maintained during the assay. Luminescence was quantified during 30 min using FlexStation3 and the SoftMaxPro 5 software (Molecular Devices).

\section{Data analysis}

All data are expressed as mean values \pm SEM and $n$ represents the number of biological replicas (animals or independent cellular experiments) and the SEM depicts the variation in the population of study. When using cell lines or isolated islets, 2-4 technical replicas were performed in each independent experiment. Statistical significance was analyzed by using GraphPad Prism 8 and the statistic test employed is indicated in the figure legends. When comparing two data samples, data was analyzed using two-sided unpaired Student's $t$ test, or twosided paired Student's $t$ test in cellular experiments since they were performed in parallel. Simultaneously, possible variance difference between the samples was assessed by F-test which showed no difference between groups thus validating the adequacy of the $t$ test analysis.
Comparisons between more than two experimental groups were performed by one-way or two-way ANOVA when the variable time is considered, since we analyzed the effect of two or more different categorical independent variables (genotype and/or treatment) on one continuous dependent variable (time). Bonferroni's post hoc test was performed after ANOVA analysis to adjust for multiple comparisons error. Differences were considered statistically significant when $P$ value $<0.05$.

\section{Availability of data and materials}

All data generated or analyzed during this study are included in this published article and its supplementary information files (Additional File 2).

\section{Supplementary Information}

The online version contains supplementary material available at https://doi. org/10.1186/s12915-021-00966-w.

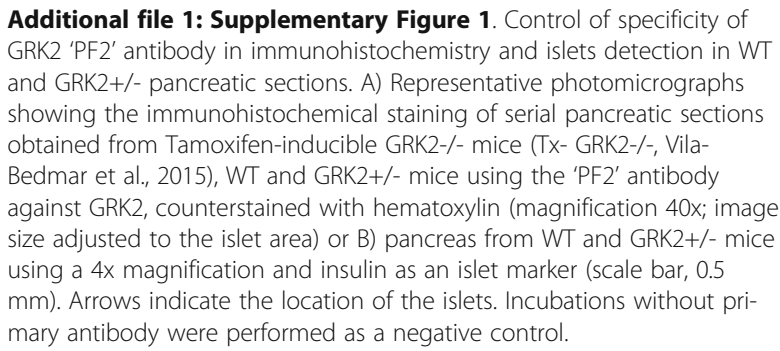
and GRK2+/- pancreatic sections. A) Representative photomicrographs showing the immunohistochemical staining of serial pancreatic sections obtained from Tamoxifen-inducible GRK2-/- mice (Tx- GRK2-/-, VilaBedmar et al., 2015), WT and GRK2+/- mice using the 'PF2' antibody against GRK2, counterstained with hematoxylin (magnification 40x; image size adjusted to the islet area) or B) pancreas from WT and GRK2+/- mice using a $4 x$ magnification and insulin as an islet marker (scale bar, 0.5 $\mathrm{mm}$ ). Arrows indicate the location of the islets. Incubations without primary antibody were performed as a negative control.

Additional file 2. Data and results supporting the conclusions of this article.

\section{Abbreviations}

Ex4: Exendin-4; EPAC2: Exchange Protein Directly Activated by CAMP 2; GLP1: Glucagon-like peptide 1; GLP-1R: Glucagon-like peptide 1 receptor;

GPCR: G protein-coupled receptor; GRK2: G protein-coupled receptor kinase 2; IR: Insulin resistance; PKA: Protein kinase A; RRP: Readily releasable pool (of insulin granules); RP: Releasable pool; T2D: Type 2 diabetes; Adrbk1: Gene for GRK2

\section{Acknowledgements}

We appreciate the help of the CBMSO Facilities, in particular Microscopy and Animal Care and the technical assistance of Laura López. We also acknowledge the institutional support to the CBMSO from Fundación Ramón Areces.

\section{Authors' contributions}

ACA performed experiments, analyzed data, designed experiments, and wrote and revised the manuscript; RVB designed experiments, analyzed data, and revised the manuscript; MM performed experiments, analyzed data, and revised the manuscript; MCS helped in the design and analysis of data and revised the manuscript; MV helped with study concepts and revised the manuscript; BJ and AT conceived and designed the experiments, analyzed data, and revised the manuscript; FM and CM provided study concept and design, interpreted experiments, supervised the study, and wrote and revised manuscript and obtained funding. All authors read and approved the final manuscript

\section{Funding}

We acknowledge support by Ministerio de Economía y Competitividad (MINECO/FEDER), Spain (grant SAF2017-84125-R to FM and CM and BFU2017-89336-R to MV); CIBER de Enfermedades Cardiovasculares (CIBERCV). Instituto de Salud Carlos III, Spain (grant CB16/11/00278 to F.M., co-funded with European FEDER contribution); CIBER de Diabetes y Enfermedades 
Metabólicas Asociadas (Ciberdem), Instituto de Salud Carlos III (CB07/08/0029 to MV); and Programa de Actividades en Biomedicina de la Comunidad de Madrid-B2017/BMD-3671-INFLAMUNE to FM; Medical Research Council to AT and $B J$.

\section{Availability of data and materials}

All data generated or analyzed during this study are included in this published article and its supplementary information files (Additional File 2)

\section{Ethics approval and consent to participate}

All animal experimentation procedures conformed to the European Guidelines for the Care and Use of Laboratory Animals (Directive 86/609) and were approved by the Ethical Committees for Animal Experimentation of the Universidad Autonoma de Madrid (PROEX 48/15).

\section{Consent for publication}

Not applicable.

\section{Competing interests}

The authors declare that they have no competing interests.

\section{Author details}

'Departamento de Biología Molecular and Centro de Biología Molecular Severo Ochoa (CBMSO) UAM-CSIC; Instituto de Investigación Sanitaria Hospital Universitario La Princesa; CIBER de Enfermedades Cardiovasculares (CIBERCV), UNIVERSIDAD AUTONOMA DE MADRID and Instituto de Salud Carlos III, Madrid, Spain. ${ }^{2}$ Departamento de Ciencias Básicas de la Salud, Facultad de Ciencias de la Salud, Universidad Rey Juan Carlos (URJC), Madrid, Spain. ${ }^{3}$ Instituto de Investigaciones Biomédicas Alberto Sols (CSIC-UAM); Centro de Investigación Biomédica en Red de Diabetes y Enfermedades Metabólicas Asociadas (Ciberdem), Madrid, Spain. ${ }^{4}$ Section of Investigative Medicine, Imperial College London, London W12 ONN, UK. ${ }^{5}$ Section of Cell Biology and Functional Genomics, Imperial College London, London W12 ONN, UK.

Received: 28 April 2020 Accepted: 22 January 2021

Published online: 03 March 2021

\section{References}

1. Röder PV, Wu B, Liu Y, Han W. Pancreatic regulation of glucose homeostasis. Experimental \& molecular medicine. 2016. https://doi.org/10.1038/emm. 2016.6.

2. Winzell MS, Ahrén B. G-protein-coupled receptors and islet functionImplications for treatment of type 2 diabetes. Pharmacol Ther. 2007;116: 437-48. https://doi.org/10.1016/j.pharmthera.2007.08.002.

3. Ruiz de Azua I, Gautam D, Jain S, Guettier J-M, Wess J. Critical metabolic roles of $\beta$-cell M3 muscarinic acetylcholine receptors. Life Sci. 2012;91:98691. doi:10.1016/j.lff.2012.04.010.

4. Begg DP, Woods SC. Interactions between the central nervous system and pancreatic islet secretions: a historical perspective. Adv Physiol Educ. 2013: 37:53-60. https://doi.org/10.1152/advan.00167.2012.

5. Reimann F, Gribble FM. G protein-coupled receptors as new therapeutic targets for type 2 diabetes. Diabetologia. 2016;59:229-33. https://doi.org/10. 1007/s00125-015-3825-z.

6. Wilcox G. Insulin and insulin resistance. Clin Biochem Rev. 2005;26:19-39.

7. Seino S, Shibasaki T, Minami K. Dynamics of insulin secretion and the clinical implications for obesity and diabetes. J Clin Invest. 2011;121:2118-25. https://doi.org/10.1172/JC145680.

8. Tokarz VL, MacDonald PE, Klip A. The cell biology of systemic insulin function. J Cell Biol. 2018;217:2273-89. https://doi.org/10.1083/jcb. 201802095.

9. Wang Z, Thurmond DC. Mechanisms of biphasic insulin-granule exocytosis roles of the cytoskeleton, small GTPases and SNARE proteins. J Cell Sci. 2009;122:893-903. https://doi.org/10.1242/jcs.034355.

10. Hou JC, Min L, Pessin JE. Insulin granule biogenesis, trafficking and exocytosis. Vitam Horm. 2009;80:473-506. https://doi.org/10.1016/500836729(08)00616-X.

11. Tomas A. Regulation of pancreatic -cell insulin secretion by actin cytoskeleton remodelling: role of gelsolin and cooperation with the MAPK signalling pathway. J Cell Sci. 2006;119:2156-67. https://doi.org/10.1242/jcs. 02942.
12. Reimann F, Gribble FM. Mechanisms underlying glucose-dependent insulinotropic polypeptide and glucagon-like peptide-1 secretion. J Diabetes Investig. 2016;7:13-9. https://doi.org/10.1111/jdi.12478.

13. Doyle ME, Egan JM. Mechanisms of action of glucagon-like peptide 1 in the pancreas. Pharmacol Ther. 2007;113:546-93. https://doi.org/10.1016/j. pharmthera.2006.11.007.

14. Nauck MA, Meier JJ. Incretin hormones: their role in health and disease. Diabetes, Obes Metab. 2018;20:5-21. https://doi.org/10.1111/dom.13129.

15. de Graaf C, Donnelly D, Wootten D, Lau J, Sexton PM, Miller L, et al. Glucagon-like peptide-1 and its class B G protein-coupled receptors: a long march to therapeutic successes. Pharmacol Rev. 2016;68:954-1013. https:// doi.org/10.1124/pr.115.011395.

16. Müller TD, Finan B, Bloom SR, D'Alessio D, Drucker DJ, Flatt PR, et al. Glucagon-like peptide 1 (GLP-1). Mol Metab. 2019;30:72-130. https://doi.org/ 10.1016/j.molmet.2019.09.010.

17. Shibasaki T, Takahashi H, Miki T, Sunaga Y, Matsumura K, Yamanaka M, et al. Essential role of Epac2/Rap1 signaling in regulation of insulin granule dynamics by cAMP. Proc Natl Acad Sci. 2007;104:19333-8. https://doi.org/10. 1073/pnas.0707054104.

18. Leech CA, Chepurny OG, Holz GG. Epac2-dependent rap1 activation and the control of islet insulin secretion by glucagon-like peptide-1. Vitam Horm. 2010;84:279-302. https://doi.org/10.1016/B978-0-12-381517-0.00010-2.

19. Alenkvist I, Gandasi NR, Barg S, Tengholm A. Recruitment of Epac2A to insulin granule docking sites regulates priming for exocytosis. Diabetes. 2017:66:2610-22. https://doi.org/10.2337/db17-0050.

20. Kaihara KA, Dickson LM, Jacobson DA, Tamarina N, Roe MW, Philipson LH, et al. $\beta$-Cell-specific protein kinase A activation enhances the efficiency of glucose control by increasing acute-phase insulin secretion. Diabetes. 2013; 62:1527-36. https://doi.org/10.2337/db12-1013.

21. Villalpando S, Cazevieille C, Fernandez A, Lamb NJ, Hani E-H. Type II PKAs are anchored to mature insulin secretory granules in INS-1 $\beta$-cells and required for CAMP-dependent potentiation of exocytosis. Biochimie. 2016; 125:32-41. https://doi.org/10.1016/j.biochi.2016.02.008.

22. Meloni AR, DeYoung MB, Lowe C, Parkes DG. GLP-1 receptor activated insulin secretion from pancreatic $\beta$-cells: mechanism and glucose dependence. Diabetes, Obes Metab. 2013;15:15-27. https://doi.org/10.1111/j. 1463-1326.2012.01663.x.

23. Hinnen D. Glucagon-like peptide 1 receptor agonists for type 2 diabetes. Diabetes Spectr. 2017;30:202-10. https://doi.org/10.2337/ds16-0026.

24. Knerr PJ, Mowery SA, Finan B, Perez-Tilve D, Tschöp MH, DiMarchi RD. Selection and progression of unimolecular agonists at the GIP, GLP-1, and glucagon receptors as drug candidates. Peptides. 2020;125:170225. https:// doi.org/10.1016/j.peptides.2019.170225.

25. Hasib A. Multiagonist unimolecular peptides for obesity and type 2 diabetes: current advances and future directions. Clin Med Insights Endocrinol Diabetes. 2020;13:117955142090584. https://doi.org/10.1177/ 1179551420905844.

26. Mayor F, Cruces-Sande M, Arcones AC, Vila-Bedmar R, Briones AM, Salaices M, et al. G protein-coupled receptor kinase 2 (GRK2) as an integrative signalling node in the regulation of cardiovascular function and metabolic homeostasis. Cell Signal. 2018;41:25-32. https:/doi.org/10.1016/j.cellsig.2017.04.002.

27. Murga C, Arcones AC, Cruces-Sande M, Briones AM, Salaices M, Mayor F Jr. G protein-coupled receptor kinase 2 (GRK2) as a potential therapeutic target in cardiovascular and metabolic diseases. Front Pharmacol. 2019;10:112. https://doi.org/10.3389/fphar.2019.00112.

28. Penela P, Murga C, Ribas C, Lafarga V, Mayor F Jr, Mayor F Jr. The complex $G$ protein-coupled receptor kinase 2 (GRK2) interactome unveils new physio-pathological targets. Br J Pharmacol. 2010;160:821-32. https://doi. org/10.1111/j.1476-5381.2010.00727.x.

29. Watari K, Nakaya M, Kurose H. Multiple functions of G protein-coupled receptor kinases. J Mol Signal. 2014;9:1. https://doi.org/10.1186/1750-2187-9-1.

30. Gurevich EV, Tesmer JJ, Mushegian A, Gurevich W. G protein-coupled receptor kinases: more than just kinases and not only for GPCRs. Pharmacol Ther. 2012;133:40-69. https://doi.org/10.1016/j.pharmthera.2011.08.001.

31. Penela P, Ribas C, Sánchez-Madrid F, Mayor F. G protein-coupled receptor kinase 2 (GRK2) as a multifunctional signaling hub. Cell Mol Life Sci. 2019;76: 4423-46. https://doi.org/10.1007/s00018-019-03274-3.

32. Ciccarelli M, Chuprun JK, Rengo G, Gao E, Wei Z, Peroutka RJ, et al. G protein-coupled receptor kinase 2 activity impairs cardiac glucose uptake and promotes insulin resistance after myocardial ischemia. Circulation. 2011; 123:1953-62. https://doi.org/10.1161/CIRCULATIONAHA.110.988642. 
33. Jaber M, Koch WJ, Rockman H, Smith B, Bond RA, Sulik KK, et al. Essential role of -adrenergic receptor kinase 1 in cardiac development and function Proc Natl Acad Sci. 1996;93:12974-9. https://doi.org/10.1073/pnas.93.23. 12974.

34. Vila-Bedmar R, Cruces-Sande M, Lucas E, Willemen HLDM, Heijnen CJ, Kavelaars A, et al. Reversal of diet-induced obesity and insulin resistance by inducible genetic ablation of GRK2. Sci Signal. 2015;8:ra73. doi:10.1126/ scisignal.aaa4374.

35. Czech MP. Insulin action and resistance in obesity and type 2 diabetes. Nat Med. 2017:23:804-14. https://doi.org/10.1038/nm.4350.

36. Mezza T, Cinti F, Cefalo CMA, Pontecorvi A, Kulkarni RN, Giaccari A. B-cell fate in human insulin resistance and type 2 diabetes: a perspective on islet plasticity. Diabetes. 2019;68:1121-9. https://doi.org/10.2337/db18-0856.

37. Longnecker DS, Gorelick F, Thompson ED. Anatomy, histology, and fine structure of the pancreas. In: The Pancreas. Chichester, UK: John Wiley \& Sons, Ltd; 2018. p. 10-23. doi:10.1002/9781119188421.ch2.

38. Dolenšek J, Rupnik MS, Stožer A. Structural similarities and differences between the human and the mouse pancreas. Islets. 2015;7:e1024405 https://doi.org/10.1080/19382014.2015.1024405.

39. Zhang H, Li J, Li Z, Luo Y. Increased GLP-1 response after gavageadministration of glucose in UCP2-deficient mice. Horm Metab Res. 2012:44: 86-90. https://doi.org/10.1055/s-0031-1298017.

40. Yaekura K, Julyan R, Wicksteed BL, Hays LB, Alarcon C, Sommers S, et al. Insulin secretory deficiency and glucose intolerance in Rab3A null mice. J Biol Chem. 2003;278:9715-21. https://doi.org/10.1074/jbc.M211352200.

41. Smith PA, Sakura H, Coles B, Gummerson N, Proks P, Ashcroft FM. Electrogenic arginine transport mediates stimulus-secretion coupling in mouse pancreatic beta-cells. J Physiol. 1997;499:625-35. https://doi.org/10. 1113/jphysiol.1997.sp021955.

42. Singhmar $P$, Huo X, Eijkelkamp N, Berciano SR, Baameur F, Mei FC, et al. Critical role for Epac1 in inflammatory pain controlled by GRK2-mediated phosphorylation of Epac1. Proc Natl Acad Sci U S A. 2016;113:3036-41. https://doi.org/10.1073/pnas.1516036113.

43. Barella LF, Rossi M, Zhu L, Cui Y, Mei FC, Cheng X, et al. $\beta$ Cell-intrinsic $\beta$ arrestin 1 signaling enhances sulfonylurea-induced insulin secretion. J Clin Invest. 2019:129:3732-7. doi:10.1172/JCl126309.

44. Göke R, Fehmann HC, Linn T, Schmidt H, Krause M, Eng J, et al. Exendin-4 is a high potency agonist and truncated exendin-(9-39)-amide an antagonist at the glucagon-like peptide 1-(7-36)-amide receptor of insulin-secreting beta-cells. J Biol Chem. 1993;268:19650-5.

45. Jones B, Buenaventura T, Kanda N, Chabosseau P, Owen BM, Scott R, et al. Targeting GLP-1 receptor trafficking to improve agonist efficacy. Nat Commun. 2018;9:1602. https://doi.org/10.1038/s41467-018-03941-2.

46. Thal DM, Yeow RY, Schoenau C, Huber J, Tesmer JJG. Molecular mechanism of selectivity among $\mathrm{G}$ protein-coupled receptor kinase 2 inhibitors. Mol Pharmacol. 2011;80:294-303. https://doi.org/10.1124/mol.111.071522.

47. Jorgensen R, Kubale V, Vrecl M, Schwartz TW, Elling CE. Oxyntomodulin differentially affects glucagon-like peptide-1 receptor $\beta$-arrestin recruitment and signaling through Ga. J Pharmacol Exp Ther. 2007;322:148-54. https:// doi.org/10.1124/jpet.107.120006.

48. Jorgensen R, Norklit Roed S, Heding A, Elling CE. Beta-arrestin2 as a competitor for GRK2 interaction with the GLP-1 receptor upon receptor activation. Pharmacology. 2011;88:174-81. https://doi.org/10.1159/ 000330742.

49. Al-Sabah S, Al-Fulaij M, Shaaban G, Ahmed HA, Mann RJ, Donnelly D, et al. The GIP receptor displays higher basal activity than the GLP-1 receptor but does not recruit GRK2 or arrestin3 effectively. PLoS One. 2014;9:e106890. https://doi.org/10.1371/journal.pone.0106890.

50. Challiss RAJ, Wess J. GPCR-G protein preassembly? Nat Chem Biol. 2011;7: 657-8. https://doi.org/10.1038/nchembio.665.

51. Ayoub MA, Al-Senaidy A, Pin J-P. Receptor-G protein interaction studied by bioluminescence resonance energy transfer: lessons from protease-activated receptor 1. Front Endocrinol (Lausanne). 2012;3. doi:10.3389/fendo.2012. 00082.

52. Wan Q, Okashah N, Inoue A, Nehmé R, Carpenter B, Tate CG, et al. Mini G protein probes for active $\mathrm{G}$ protein-coupled receptors (GPCRs) in live cells. J Biol Chem. 2018;293:7466-73. https://doi.org/10.1074/jbc.RA118.001975.

53. Nguyen AH, Thomsen ARB, Cahill TJ, Huang R, Huang L-Y, Marcink T, et al. Structure of an endosomal signaling GPCR-G protein- $\beta$-arrestin megacomplex. Nat Struct Mol Biol. 2019;26:1123-31. https://doi.org/10.1038/ s41594-019-0330-y.
54. Thomsen ARB, Plouffe B, Cahill TJ, Shukla AK, Tarrasch JT, Dosey AM, et al. GPCR-G protein- $\beta$-arrestin super-complex mediates sustained $G$ protein signaling. Cell. 2016;166:907-19. https://doi.org/10.1016/j.cell.2016.07.004.

55. Tomas A, Jones B, Leech C. New insights into beta-cell GLP-1 receptor and CAMP signaling. J Mol Biol. 2020;432:1347-66. https://doi.org/10.1016/j.jmb. 2019.08.009.

56. Kuna RS, Girada SB, Asalla S, Vallentyne J, Maddika S, Patterson JT, et al. Glucagon-like peptide-1 receptor-mediated endosomal CAMP generation promotes glucose-stimulated insulin secretion in pancreatic $\beta$-cells. Am J Physiol Metab. 2013;305:E161-70. https://doi.org/10.1152/ajpendo.00551. 2012.

57. Girada SB, Kuna RS, Bele S, Zhu Z, Chakravarthi NR, DiMarchi RD, et al. Gas regulates glucagon-like peptide 1 receptor-mediated cyclic AMP generation at Rab5 endosomal compartment. Mol Metab. 2017;6:1173-85. https://doi. org/10.1016/j.molmet.2017.08.002.

58. Kong KC, Gandhi U, Martin TJ, Anz CB, Yan H, Misior AM, et al. Endogenous G s -coupled receptors in smooth muscle exhibit differential susceptibility to GRK2/3-mediated desensitization †. Biochemistry. 2008;47:9279-88. https://doi.org/10.1021/bi801056w.

59. Lowther KM, Uliasz TF, Götz KR, Nikolaev VO, Mehlmann LM. Regulation of constitutive GPR3 signaling and surface localization by GRK2 and $\beta$-arrestin2 overexpression in HEK293 cells. PLoS One. 2013;8:e65365. https://doi.org/ 10.1371/journal.pone.0065365.

60. Salazar NC, Vallejos X, Siryk A, Rengo G, Cannavo A, Liccardo D, et al. GRK2 blockade with $\beta A R K c t$ is essential for cardiac $\beta 2$-adrenergic receptor signaling towards increased contractility. Cell Commun Signal. 2013;11:64. https://doi.org/10.1186/1478-811X-11-64.

61. Sallese M, Mariggiò S, D'Urbano E, lacovelli L, De Blasi A, Mariggio S, et al. Selective regulation of $\mathrm{G} q$ signaling by $\mathrm{G}$ protein-coupled receptor kinase 2: direct interaction of kinase $\mathrm{N}$ terminus with activated galphaq. Mol Pharmacol. 2000;57:826-31.

62. Jorgensen R, Martini L, Schwartz TW, Elling CE. Characterization of glucagon-like peptide-1 receptor $\beta$-arrestin 2 interaction: a high-affinity receptor phenotype. Mol Endocrinol. 2005;19:812-23. https://doi.org/10. 1210/me.2004-0312.

63. Tseng $C-C C$, Zhang $X-Y Y$. Role of $G$ protein-coupled receptor kinases in glucose-dependent insulinotropic polypeptide receptor signaling. Endocrinology. 2000;141:947-52. https://doi.org/10.1210/endo.141.3.7365.

64. Ravier MA, Leduc M, Richard J, Linck N, Varrault A, Pirot N, et al. $\beta$ Arrestin2 plays a key role in the modulation of the pancreatic beta cell mass in mice. Diabetologia. 2014;57:532-41. https://doi.org/10.1007/ s00125-013-3130-7.

65. Zhu L, Almaça J, Dadi PK, Hong H, Sakamoto W, Rossi M, et al. $\beta$-arrestin-2 is an essential regulator of pancreatic $\beta$-cell function under physiological and pathophysiological conditions. Nat Commun. 2017;8:14295. doi:10.1038/ ncomms14295.

66. Zhang M, Zhu Y, Mu K, Li L, Lu J, Zhao J, et al. Loss of $\beta$-arrestin2 mediates pancreatic-islet dysfunction in mice. Biochem Biophys Res Commun. 2013; 435:345-9. https://doi.org/10.1016/j.bbrc.2013.04.079.

67. Sonoda N, Imamura T, Yoshizaki T, Babendure JL, Lu J-C, Olefsky JM. $\beta$ Arrestin-1 mediates glucagon-like peptide-1 signaling to insulin secretion in cultured pancreatic cells. Proc Natl Acad Sci. 2008;105:6614-9. doi:10.1073/ pnas.0710402105.

68. Jones B, Bloom SR, Buenaventura T, Tomas A, Rutter GA. Control of insulin secretion by GLP-1. Peptides. 2018;100:75-84. https://doi.org/10.1016/j. peptides.2017.12.013.

69. Whalen EJ, Rajagopal S, Lefkowitz RJ. Therapeutic potential of $\beta$-arrestinand $G$ protein-biased agonists. Trends Mol Med. 2011;17:126-39. https://doi. org/10.1016/j.molmed.2010.11.004.

70. Grundmann M, Merten N, Malfacini D, Inoue A, Preis P, Simon K, et al. Lack of beta-arrestin signaling in the absence of active $G$ proteins. Nat Commun. 2018;9:341. https://doi.org/10.1038/s41467-017-02661-3.

71. Fu Z, Gilbert ER, Liu D. Regulation of insulin synthesis and secretion and pancreatic Beta-cell dysfunction in diabetes. Curr Diabetes Rev. 2013;9:2553. https://doi.org/10.2174/1573399811309010025.

72. Daniel S, Noda M, Straub SG, Sharp GW. Identification of the docked granule pool responsible for the first phase of glucose-stimulated insulin secretion. Diabetes. 1999:48:1686-90. https:/doi.org/10.2337/diabetes.48.9.1686.

73. Maechler $P$, Wollheim CB. Mitochondrial signals in glucose-stimulated insulin secretion in the beta cell. J Physiol. 2000;529:49-56. https://doi.org/ 10.1111/j.1469-7793.2000.00049.x 
74. Gerich JE. Is reduced first-phase insulin release the earliest detectable abnormality in individuals destined to develop type 2 diabetes? Diabetes. 2002;51 Supplement 1:S117-21. doi:10.2337/diabetes.51.2007.S117.

75. Kanat M, Norton L, Winnier D, Jenkinson C, DeFronzo RA, Abdul-Ghani MA Impaired early- but not late-phase insulin secretion in subjects with impaired fasting glucose. Acta Diabetol. 2011;48:209-17. https://doi.org/10. 1007/s00592-011-0285-x

76. Cheng K, Andrikopoulos S, Gunton JE. First phase insulin secretion and type 2 diabetes. Curr Mol Med. 2013;13:126-39. https://doi.org/10.2174/ 1566524011307010126.

77. Aroda VR. A review of GLP-1 receptor agonists: evolution and advancement, through the lens of randomised controlled trials. Diabetes, Obes Metab. 2018;20:22-33. https://doi.org/10.1111/dom.13162.

78. Sharma D, Verma S, Vaidya S, Kalia K, Tiwari V. Recent updates on GLP-1 agonists: current advancements \& challenges. Biomed Pharmacother. 2018; 108:952-62. https://doi.org/10.1016/j.biopha.2018.08.088.

79. Holst JJ. From the incretin concept and the discovery of GLP-1 to today's diabetes therapy. Front Endocrinol (Lausanne). 2019;10. doi:10.3389/fendo. 2019.00260.

80. Fehse F, Trautmann M, Holst JJ, Halseth AE, Nanayakkara N, Nielsen LL, et al. Exenatide augments first- and second-phase insulin secretion in response to intravenous glucose in subjects with type 2 diabetes. J Clin Endocrinol Metab. 2005;90:5991-7. https://doi.org/10.1210/jc.2005-1093.

81. Rowlands J, Heng J, Newsholme P, Carlessi R. Pleiotropic effects of GLP-1 and analogs on cell signaling, metabolism, and function. Front Endocrinol (Lausanne). 2018;9. doi:10.3389/fendo.2018.00672.

82. Zummo FP, Cullen KS, Honkanen-Scott M, Shaw JAM, Lovat PE, Arden C Glucagon-like peptide 1 protects pancreatic $\beta$-cells from death by increasing autophagic flux and restoring lysosomal function. Diabetes. 2017; 66:1272-85. https://doi.org/10.2337/db16-1009.

83. Herzberg-Schäfer S, Heni M, Stefan N, Häring H-U, Fritsche A. Impairment of GLP1-induced insulin secretion: role of genetic background, insulin resistance and hyperglycaemia. Diabetes, Obes Metab. 2012;14:85-90. https://doi.org/10.1111/j.1463-1326.2012.01648.x

84. Rajan S, Dickson LM, Mathew E, Orr CMO, Ellenbroek JH, Philipson LH, et al. Chronic hyperglycemia downregulates GLP-1 receptor signaling in pancreatic $\beta$-cells via protein kinase A. Mol Metab. 2015;4:265-76. https:// doi.org/10.1016/..molmet.2015.01.010.

85. Lucas E, Vila-Bedmar R, Arcones AC, Cruces-Sande M, Cachofeiro V, Mayor F $\mathrm{Jr}$, et al. Obesity-induced cardiac lipid accumulation in adult mice is modulated by $\mathrm{G}$ protein-coupled receptor kinase 2 levels. Cardiovasc Diabetol. 2016;15:155. https://doi.org/10.1186/s12933-016-0474-6.

86. Cruces-Sande M, Vila-Bedmar R, Arcones AC, Gonzalez-Rodriguez A, Rada P, Gutierrez-de-Juan $V$, et al. Involvement of $G$ protein-coupled receptor kinase 2 (GRK2) in the development of non-alcoholic steatosis and steatohepatitis in mice and humans. Biochim Biophys Acta Mol Basis Dis. 1864;2018:365567. https://doi.org/10.1016/j.bbadis.2018.09.027

87. Arcones AC, Cruces-Sande M, Ramos P, Mayor F, Murga C. Sex differences in high fat diet-induced metabolic alterations correlate with changes in the modulation of GRK2 levels. Cells. 2019;8:1464. https://doi.org/10.3390/ cells8111464.

88. Kang T, Boland BB, Alarcon C, Grimsby JS, Rhodes CJ, Larsen MR. Proteomic analysis of restored insulin production and trafficking in obese diabetic mouse pancreatic islets following euglycemia. J Proteome Res. 2019;18: 3245-58. https://doi.org/10.1021/acs.jproteome.9b00160.

89. Kang T, Boland BB, Jensen P, Alarcon C, Nawrocki A, Grimsby JS, et al. Characterization of signaling pathways associated with pancreatic $\beta$-cell adaptive flexibility in compensation of obesity-linked diabetes in $\mathrm{db} / \mathrm{db}$ mice. Mol Cell Proteomics. 2020;19:971-93. https://doi.org/10.1074/mcp.RA119.001882.

90. Robertson RP, Raymond RH, Lee DS, Calle RA, Ghosh A, Savage PJ, et al. Arginine is preferred to glucagon for stimulation testing of $\beta$-cell function. Am J Physiol Metab. 2014;307:E720-7. https://doi.org/10.1152/ajpendo. 00149.2014

91. Mirasierra M, Fernández-Pérez A, Díaz-Prieto N, Vallejo M. Alx3-deficient mice exhibit decreased insulin in beta cells, altered glucose homeostasis and increased apoptosis in pancreatic islets. Diabetologia. 2011;54:403-14. https://doi.org/10.1007/s00125-010-1975-6.

92. Nogues L, Reglero C, Rivas V, Salcedo A, Lafarga V, Neves M, et al. G protein-coupled receptor kinase 2 (GRK2) promotes breast tumorigenesis through a HDAC6-Pin1 axis. EBioMedicine. 2016;13:132-45. https://doi.org/ 10.1016/j.ebiom.2016.09.030.
93. Lucas E, Jurado-Pueyo M, Fortuño MA, Fernández-Veledo S, Vila-Bedmar R, Jiménez-Borreguero $L$, et al. Downregulation of $\mathrm{G}$ protein-coupled receptor kinase 2 levels enhances cardiac insulin sensitivity and switches on cardioprotective gene expression patterns. Biochim Biophys Acta - Mol Basis Dis. 1842;2014:2448-56. https://doi.org/10.1016/j.bbadis.2014.09.004.

94. Naylor J, Suckow AT, Seth A, Baker DJ, Sermadiras I, Ravn P, et al. Use of CRISPR/Cas9-engineered INS-1 pancreatic $\beta$ cells to define the pharmacology of dual GIPR/GLP-1R agonists. Biochem J. 2016;473:2881-91. https://doi.org/10.1042/BCJ20160476.

95. Miess E, Gondin AB, Yousuf A, Steinborn R, Mösslein N, Yang $Y$, et al. Multisite phosphorylation is required for sustained interaction with GRKs and arrestins during rapid $\mu$-opioid receptor desensitization. Sci Signal. 2018, 11:eaas9609. doi:10.1126/scisignal.aas9609.

96. Machleidt T, Woodroofe CC, Schwinn MK, Méndez J, Robers MB, Zimmerman $\mathrm{K}$, et al. NanoBRET - a novel BRET platform for the analysis of protein-protein interactions. ACS Chem Biol. 2015;10:1797-804. https://doi. org/10.1021/acschembio.5b00143.

97. Mo X-L, Luo Y, Ivanov AA, Su R, Havel JJ, Li Z, et al. Enabling systematic interrogation of protein-protein interactions in live cells with a versatile ultra-high-throughput biosensor platform. J Mol Cell Biol. 2016;8:271-81. https://doi.org/10.1093/jmcb/mjv064.

98. Miyazaki J-I, Araki K, Yamato E, Ikegami H, Asano T, Shibasaki Y, et al. Establishment of a pancreatic $\beta$ cell line that retains glucose-inducible insulin secretion: special reference to expression of glucose transporter isoforms. Endocrinology. 1990;127:126-32. https://doi.org/10.1210/endo-127$1-126$

99. Lilla V, Webb G, Rickenbach K, Maturana A, Steiner DF, Halban PA, et al. Differential gene expression in well-regulated and dysregulated pancreatic ß-cell (MIN6) sublines. Endocrinology. 2003;144:1368-79. https://doi.org/10. 1210/en.2002-220916.

100. Inoue A, Raimondi F, Kadji FMN, Singh G, Kishi T, Uwamizu A, et al. Illuminating G-protein-coupling selectivity of GPCRs. Cell. 2019;177:19331947.e25. doi:10.1016/j.cell.2019.04.044.

101. Lucey M, Pickford P, Bitsi S, Minnion J, Ungewiss J, Schoeneberg K, et al. Disconnect between signalling potency and in vivo efficacy of pharmacokinetically optimised biased glucagon-like peptide-1 receptor agonists. Mol Metab. 2020::100991. doi:10.1016/j.molmet.2020.100991.

102. Kroeze WK, Sassano MF, Huang X-P, Lansu K, McCorvy JD, Giguère PM, et al. PRESTO-Tango as an open-source resource for interrogation of the druggable human GPCRome. Nat Struct Mol Biol. 2015;22:362-9. https://doi. org/10.1038/nsmb.3014

\section{Publisher's Note}

Springer Nature remains neutral with regard to jurisdictional claims in published maps and institutional affiliations.

Ready to submit your research? Choose BMC and benefit from:

- fast, convenient online submission

- thorough peer review by experienced researchers in your field

- rapid publication on acceptance

- support for research data, including large and complex data types

- gold Open Access which fosters wider collaboration and increased citations

- maximum visibility for your research: over $100 \mathrm{M}$ website views per year

At BMC, research is always in progress.

Learn more biomedcentral.com/submissions 